\title{
Evaluation of coupled ocean-atmosphere simulations of the mid-Holocene using palaeovegetation data from the northern hemisphere extratropics
}

\author{
J. Wohlfahrt · S. P. Harrison · P. Braconnot • \\ C. D. Hewitt · A. Kitoh · U. Mikolajewicz • \\ B. L. Otto-Bliesner $\cdot$ S. L. Weber
}

Received: 6 July 2007/ Accepted: 21 April 2008/Published online: 15 May 2008

(C) The Author(s) 2008

\begin{abstract}
We have used the BIOME4 biogeographybiochemistry model and comparison with palaeovegetation data to evaluate the response of six ocean-atmosphere general circulation models to mid-Holocene changes in orbital forcing in the mid- to high-latitudes of the northern hemisphere. All the models produce: (a) a northward shift of the northern limit of boreal forest, in response to simulated summer warming in high-latitudes. The northward shift is markedly asymmetric, with larger shifts in Eurasia than in North America; (b) an expansion of xerophytic vegetation in mid-continental North America and Eurasia, in response to increased temperatures during the growing season; (c) a northward expansion of temperate forests in eastern North America, in response to simulated winter warming. The northward shift of the northern limit of boreal forest and the northward expansion of temperate forests in North America are supported
\end{abstract}

J. Wohlfahrt · S. P. Harrison $(\bowtie)$

School of Geographical Sciences, University of Bristol, University Road, Bristol BS8 1SS, UK

e-mail: sandy.harrison@bristol.ac.uk

J. Wohlfahrt · S. P. Harrison

Max Planck Institute for Biogeochemistry,

PO Box 1001 64, Jena 07701, Germany

e-mail: jens.wohlfahrt@bgc-jena.mpg.de

\section{P. Braconnot}

Lab. CNRS-CEA, Lab. des Sciences du Climat et de 1'Environnement, D.S.M./Orme des Merisiers/Bat. 709, CEA/Saclay, CEA/Saclay Gif sur Yvette 91191, France e-mail: pasb@1sce.saclay.cea.fr

C. D. Hewitt

Hadley Centre for Climate Prediction and Research, Met Office, Fitzroy Road, Exeter, Devon EX1 3PB, UK

e-mail: chris.hewitt@metoffice.gov.uk by palaeovegetation data. The expansion of xerophytic vegetation in mid-continental North America is consistent with palaeodata, although the extent may be over-estimated. The simulated expansion of xerophytic vegetation in Eurasia is not supported by the data. Analysis of an asynchronous coupling of one model to an equilibriumvegetation model suggests vegetation feedback exacerbates this mid-continental drying and produces conditions more unlike the observations. Not all features of the simulations are robust: some models produce winter warming over Europe while others produce winter cooling. As a result, some models show a northward shift of temperate forests (consistent with, though less marked than, the expansion shown by data) and others produce a reduction in temperate forests. Elucidation of the cause of such differences is a focus of the current phase of the Palaeoclimate Modelling Intercomparison Project.

\footnotetext{
A. Kitoh

Climate Research Department, Meteorological Research Institute, Nagamine 1-1, Tsukuba, Ibaraki 305, Japan

e-mail: kitoh@mri-jma.go.jp

U. Mikolajewicz

Max-Planck-Institute for Meteorologie,

Bundesstr. 55, Hamburg 20146, Germany

e-mail: mikolajewicz@dkrz.de

B. L. Otto-Bliesner

Climate and Global Dynamics Division,

National Control for Atmospheric Research,

Boulder, CO 80307, USA

e-mail: ottobli@ucar.edu

S. L. Weber

Royal Netherlands Meteorological Institute,

P.O. Box 201, DeBilt 3730 AE, Netherlands

e-mail: weber@knmi.nl
} 
Keywords Mid-Holocene · Extratropical climates · Climate model evaluation - Ocean feedback .

Tundra-taiga boundary $\cdot$ Mid-continental aridity .

Data-model comparisons · Pollen

reconstructions of vegetation

\section{Introduction}

A variety of environmental indicators show that northern hemisphere climates were radically different from present during the mid-Holocene (ca. 6,000 years ago, $6 \mathrm{ka}$ ). The most pronounced changes occur in the Afro-Asian region, where the expansion of moisture-demanding vegetation and the presence of large lakes attest to an enhancement of the northern hemisphere monsoons (Street-Perrott and Perrott 1993; Jolly et al. 1998; Yu et al. 1998; Prentice et al. 2000). In the mid- to high-northern latitudes, the expansion of boreal forest at the expense of tundra indicates warmer conditions during the growing season (TEMPO 1996; Tarasov et al. 1998; Edwards et al. 2000; MacDonald et al. 2000; Prentice et al. 2000; Williams et al. 2000; CAPE Project Members 2001; Bigelow et al. 2003). Both of these regional changes are associated with changes in incoming solar radiation (insolation) consequent on changes in the earth's orbit: at $6 \mathrm{ka}$, northern-hemisphere insolation was ca. 5\% greater than today during summer and ca. 5\% less than today in winter.

Simulations with atmospheric general circulation models (AGCMs) show that the observed changes in regional climates at $6 \mathrm{ka}$ are partly caused by the atmospheric response to orbital forcing (Kutzbach 1981; Kutzbach and Otto-Bliesner 1982; Kutzbach and Street-Perrott 1985; Kutzbach and Guetter 1986; COHMAP members 1988; TEMPO 1996; Masson and Joussaume 1997; Joussaume et al. 1999). However, analyses conducted in the Palaeoclimate Modelling Intercomparison Project (PMIP: Joussaume and Taylor 2000) show that observed changes in the monsoon regions were larger than can be explained by the atmospheric response to orbital forcing alone (Joussaume et al. 1999). Similarly, AGCMs do not reproduce the pronounced asymmetry in the changes in the tundra-taiga boundary shown by the observations (TEMPO 1996; Kohfeld and Harrison 2000). These mismatches between simulated and observed regional climates indicate the importance of feedbacks in amplifying or modifying the atmospheric response to orbital forcing. Changes in ocean conditions have been invoked as important feedbacks on both monsoon and high-latitude climates (Kutzbach and Liu 1997; Hewitt and Mitchell 1998; Liu et al. 1999; Otto-Bliesner 1999; Braconnot et al. 2000a; Texier et al. 2000; Liu et al. 2004).
Several modelling groups have run coupled oceanatmosphere model (OAGCM) simulations of $6 \mathrm{ka}$ (Hewitt and Mitchell 1998; Braconnot et al. 1999; Otto-Bliesner 1999; Braconnot et al. 2000b; Voss and Mikolajewicz 2001; Weber 2001; Kitoh and Murakami 2002; Mikolajewicz et al. 2003). These simulations document the importance of ocean feedbacks for northern hemisphere climates, and should allow the strength of this feedback to be quantified. However, models differ in their construction and, as analyses of AGCM simulations conducted in the first phase of PMIP show, these differences can be important for the simulation of regional climates (Harrison et al. 1998; Joussaume et al. 1999). Unfortunately, because the existing $6 \mathrm{ka}$ OAGCM simulations also use slightly different specifications of the $6 \mathrm{ka}$ climate forcing, the diagnosis of differences caused by model parameterisation is not entirely straightforward. PMIP is currently running fully coupled OAGCM simulations of $6 \mathrm{ka}$ climate with identical forcing (Harrison et al. 2002). Our ultimate goal is to use palaeovegetation data to assess the new PMIP simulations. The comparison of existing published simulations presented here is designed to help in (a) identifying how far specific regional climate changes are robust and how large the differences between models are, and (b) developing a robust methodology for model evaluation.

In this paper, we analyse the existing OAGCM simulations of the 6 ka climate, focusing on the changes in the midto high-northern latitudes. The spatial focus is motivated by the existence of a synthesis of pollen data from the high latitudes made as part of PAIN (the Pan-Arctic INitiative: Bigelow et al. 2003). These data provide a target against which to assess the realism of the $6 \mathrm{ka}$ simulations. To facilitate comparisons with these data, OAGCM output is used to drive an equilibrium vegetation model (BIOME4: Kaplan et al. 2003) in order to derive the changes in vegetation patterns implied by the simulated climate changes. The simulated vegetation integrates changes in the seasonal cycles of both temperature and moisture, and thus provides a single diagnostic summarising the regional climate changes.

In a previous study of mid-Holocene simulations made with the Institute Pierre Simone Laplace (IPSL) OAGCM, we identified a number of vegetation changes that were characteristic of the response of the coupled ocean-atmosphere system to orbital forcing (Wohlfahrt et al. 2004). These features include:

(1) a northward shift of the northern boundary of the boreal forest, in response to increased growing season warmth driven by increased insolation in summer and the prolongation of warm conditions into the autumn caused by ocean feedbacks;

(2) an expansion of xerophytic vegetation in midcontinental regions, due to reduced precipitation 
during spring and summer driven by the atmospheric response to orbital changes enhanced by ocean feedback;

(3) a northward expansion of temperate forests in eastern North America, resulting from ocean feedback offsetting the orbitally induced winter cooling;

(4) a southward displacement of temperate forests in Europe, where ocean feedback was insufficient to offset the orbitally forced winter cooling.

In our analysis of the published OAGCM simulations, we focus on these four responses. This allows us to determine whether the coupled-model responses to orbital forcing are robust or whether inter-model differences in e.g. parameterisations or spatial resolution produce discernable differences at a regional scale. We then examine whether the robust changes in simulated vegetation patterns are realistic and, in the case of non-robust changes, whether the available palaeoenvironmental data are sufficient to determine which response is correct.

\section{Methods}

To evaluate the response of the coupled ocean-atmosphere system to $6 \mathrm{ka}$ orbital forcing we have used the output of 7 simulations made with 6 different OAGCMs to drive an equilibrium biome model (BIOME4: Kaplan et al. 2003). The simulated vegetation response integrates several aspects of climate (including changes in the seasonal cycles of temperature and moisture balance) and thus provides a single diagnostic of simulated climate changes. This approach also facilitates comparison with palaeovegetation data, allowing the realism of the simulated regional patterns to be assessed. Here, as in our former analyses (Wohlfahrt et al. 2004), the simulated vegetation patterns north of $40^{\circ} \mathrm{N}$ are compared with pollen-based vegetation reconstructions derived by combining the PAIN (PanArctic INitiative: Bigelow et al. 2003) and BIOME 6000 (Palaeovegetation Mapping Project: Prentice et al. 2000) data sets.

\section{Climate model simulations}

Six modelling groups (Table 1) have made simulations of the response of coupled ocean-atmosphere system to $6 \mathrm{ka}$ orbital forcing. One of these groups (CSM) has made two simulations, which differ with respect to the specification of the boundary conditions. The IPSL-CM1 simulation is the same simulation we used for our former analyses (Wohlfahrt et al. 2004) but has been run for longer. Thus, we are able to use a longer period of time for deriving climate averages to drive BIOME4 than was possible before. The ECHAM3/LSG model was run in periodic synchronous coupling mode; this scheme consists of alternating synchronous (15 months) and ocean-only integrations (48 months) and was used to reduce computer time (Voss and Mikolajewicz 2001). All the other models were run in fully coupled (i.e. synchronous) mode throughout the simulations.

The major change in climate forcing at $6 \mathrm{ka}$ is the change in the seasonal and latitudinal distribution of insolation as a consequence of changes in the earth's orbit (Berger 1978). At $6 \mathrm{ka}$, northern hemisphere insolation was ca. $5 \%$ greater than today in summer and ca. 5\% less in winter. All of the simulations adopted the Palaeoclimate Modelling Intercomparison Project (PMIP: Joussaume and Taylor 2000) definitions for modern and $6 \mathrm{ka}$ insolation. Atmospheric $\mathrm{CO}_{2}$ concentration $\left[\mathrm{CO}_{2}\right]$ at $6 \mathrm{ka}$ was lower than today and marginally lower than pre-industrial levels (Raynaud et al. 1993). In the first phase of PMIP, based on the exercise of atmospheric general circulation models (AGCMs), it was assumed that the impact of changes in $\left[\mathrm{CO}_{2}\right]$ on models with prescribed ocean conditions was negligible (Hewitt and Mitchell 1998). In its second phase (Harrison et al. 2002), PMIP has adopted the convention that the control and $6 \mathrm{ka}$ simulations use the same $\left[\mathrm{CO}_{2}\right]$. Modelling groups had the choice of using a level of 345 ppmv for both simulations or, in the case where the group used a pre-existing control simulation, of setting the $6 \mathrm{ka}$ $\left[\mathrm{CO}_{2}\right]$ to be the same as in the control simulation. Five out of the seven OAGCM simulations examined here adopted the PMIP2 convention of using the same $\left[\mathrm{CO}_{2}\right]$ for the control and $6 \mathrm{ka}$ experiments (Table 1). Three have used "modern" $\left[\mathrm{CO}_{2}\right]$ values (323 or $345 \mathrm{ppmv}$ ) for both experiments. The HADCM2 simulation used a pre-industrial (280 ppmv) level for both experiments. Only one modelling group (ECHAM) did not follow the PMIP2 protocol: the control was run with $345 \mathrm{ppmv}\left[\mathrm{CO}_{2}\right]$ and the 6 ka simulation with $280 \mathrm{ppmv}\left[\mathrm{CO}_{2}\right]$. We can investigate whether this difference in forcing has a significant impact on simulated regional climates using an additional simulation made with the $\mathrm{CSM}$ in which $\left[\mathrm{CO}_{2}\right]$ was reduced from the control value of 355 ppmv to a 6 ka value of 280 ppmv. Finally, in those models that explicitly prescribe other greenhouse gases, these were set to be the same in the control and 6 ka simulations.

The impacts of differences in the specification of $\left[\mathrm{CO}_{2}\right]$ between the various simulations are likely to be small compared to the impact of differences in model formulation (Table 2). However, there are considerable differences between the models in the treatment of model sub-components known to be important for high-latitude climates (Table 2). Changes in the extent of Arctic sea-ice, for example, have large impacts on the regional climates of the 
Table 1 The experimental design and boundary conditions used by each of the OAGCMs for the control and 6 ka climate simulations

\begin{tabular}{|c|c|c|c|c|c|c|c|}
\hline \multirow[t]{2}{*}{ Model code } & \multicolumn{2}{|l|}{ Spin-up } & \multirow{2}{*}{ 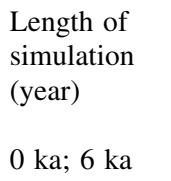 } & \multirow{2}{*}{$\begin{array}{l}\text { Length of } \\
\text { averaging } \\
\text { period } \\
\text { (year) } \\
0 \mathrm{ka} ; 6 \mathrm{ka}\end{array}$} & \multirow[t]{2}{*}{ Insolation } & \multicolumn{2}{|l|}{$\mathrm{CO}_{2}$} \\
\hline & Control & $6 \mathrm{ka}$ & & & & Control & $6 \mathrm{ka}$ \\
\hline CSM1.2 & 0 accelerated & From control year 275 & $400 ; 50$ & $50 ; 50$ & PMIP & 280 & 280 \\
\hline CSM1.2A & 0 accelerated & From control year 275 & $400 ; 50$ & $50 ; 50$ & PMIP & 355 & 280 \\
\hline ECBILT & Coupled 3,000 yrs & 500 years & $500 ; 500$ & $50 ; 50$ & PMIP & 345 & 345 \\
\hline HADCM2 & $510 \mathrm{yrs}$ & 60 years & $210 ; 210$ & $130 ; 150$ & PMIP & 323 & 323 \\
\hline ЕСНАM & 700 yrs & 700 years & 1,$000 ; 1,000$ & $300 ; 300$ & PMIP & 345 & 280 \\
\hline IPSL-CM1 & $\begin{array}{l}\text { Initial state: year } 10 \text { of coupled } \\
\text { simulation with surface restoring to } \\
\text { climatological SSTs; } 40 \text { years spin- } \\
\text { up }\end{array}$ & $\begin{array}{l}\text { Started from year } 20 \text { of } \\
\text { post spin-up control; } \\
40 \text { years spin-up }\end{array}$ & $150 ; 150$ & $70 ; 70$ & PMIP & 345 & 345 \\
\hline MRI CGCM1 & 0 accelerated & 50 years accelerated & $210 ; 210$ & $50 ; 60$ & PMIP & 345 & 345 \\
\hline
\end{tabular}

northern extratropics (Kutzbach and Guetter 1986; Mitchell et al. 1988; Kutzbach et al. 1993), and differences in sea-ice parameterisation result in large differences in seaice extent in response to a given forcing (Hewitt et al. 2001; Vavrus and Harrison 2003). Most of the coupled models analysed here use a simple thermodynamic treatment of sea-ice based on the Semtner (1976) formulation (Table 2). However, they differ in the number of ice layers considered. Furthermore, the CSM1.2, HADCM2 and MRI models also incorporate an explicit treatment of leads in the ice and some aspects of ice dynamics through allowing advection by ocean currents. Northern high-latitude climates are also known to be affected by changes in the amount of snow and the nature of the vegetation cover (Bonan et al. 1992; Douville and Royer 1996; Levis et al. 2000; Brovkin et al. 2003). Again, the models analysed here have land-surface schemes of varying complexity. Thus, the treatment of soil moisture ranges from simple single-bucket schemes (e.g. ECBILT) to multi-layer soils with separate calculation of moisture balance and soil temperature (e.g. CSM1.2, HADCM2, ECHAM). Some of the models do not allow vegetation cover to modulate water- and energy-fluxes at the land surface (e.g. ECBILT, MRI) whereas the more complex land-surface schemes (e.g. LSM 1.0: Bonan 1998; SECHIBA: Ducoudré et al. 1993) distinguish multiple vegetation types. All of the models have a prognostic snow module, but again vary in how snow cover is estimated. Thus, in contrast to the comparatively small impact expected as a result of differences in boundary conditions between the simulations, we expect differences in model parameterisation to have much larger effects.

The models also have different spatial resolutions (Table 2), ranging from the relatively low-resolution ECBILT model $(64 \times 32$ grid cells for both the atmosphere and the ocean $)$ to the higher-resolution HADCM2 $(96 \times 73$ grid cells for both atmosphere and ocean). Some of the models (e.g. CSM, IPSL and MRI) have higher resolution in the ocean than in the atmosphere. Differences in spatial resolution could be important in determining how well individual models resolve e.g. westerly storm tracks (Kageyama et al. 1999).

Finally, the models differ in the techniques used to spinup the simulations, the length of simulation and in the length of interval over which mean climate statistics are obtained (Table 1). All of the simulations are in quasiequilibrium with the $6 \mathrm{ka}$ forcing and the ensemble climate statistics are in each case based on a minimum of 50 years, sufficient to ensure that the values are representative of the mean state of the $6 \mathrm{ka}$ climate. Comparison of biome simulations calculated using the 20-year average and a 70-year average of climate data from the IPSL-CM1 model shows differences in averaging period can have an impact on the simulated area of specific biomes of up to $20 \%$, which reflects the large interannual to decadal variability of climate in mid- and high-latitudes.

\subsection{BIOME4 simulations}

Models of the BIOME family are equilibrium biogeography models which simulate the distribution of major vegetation types (biomes) as a function of the seasonal cycle of temperature, precipitation, sunshine and soil moisture conditions. The climate data used to run the model can either be derived from observations or, as here, from the output of climate model simulations.

BIOME4 is the latest version of the BIOME model family and was explicitly developed in order to resolve a range of high-latitude vegetation types (Kaplan et al. 2003). BIOME4 distinguishes 27 biomes, including 5 types 


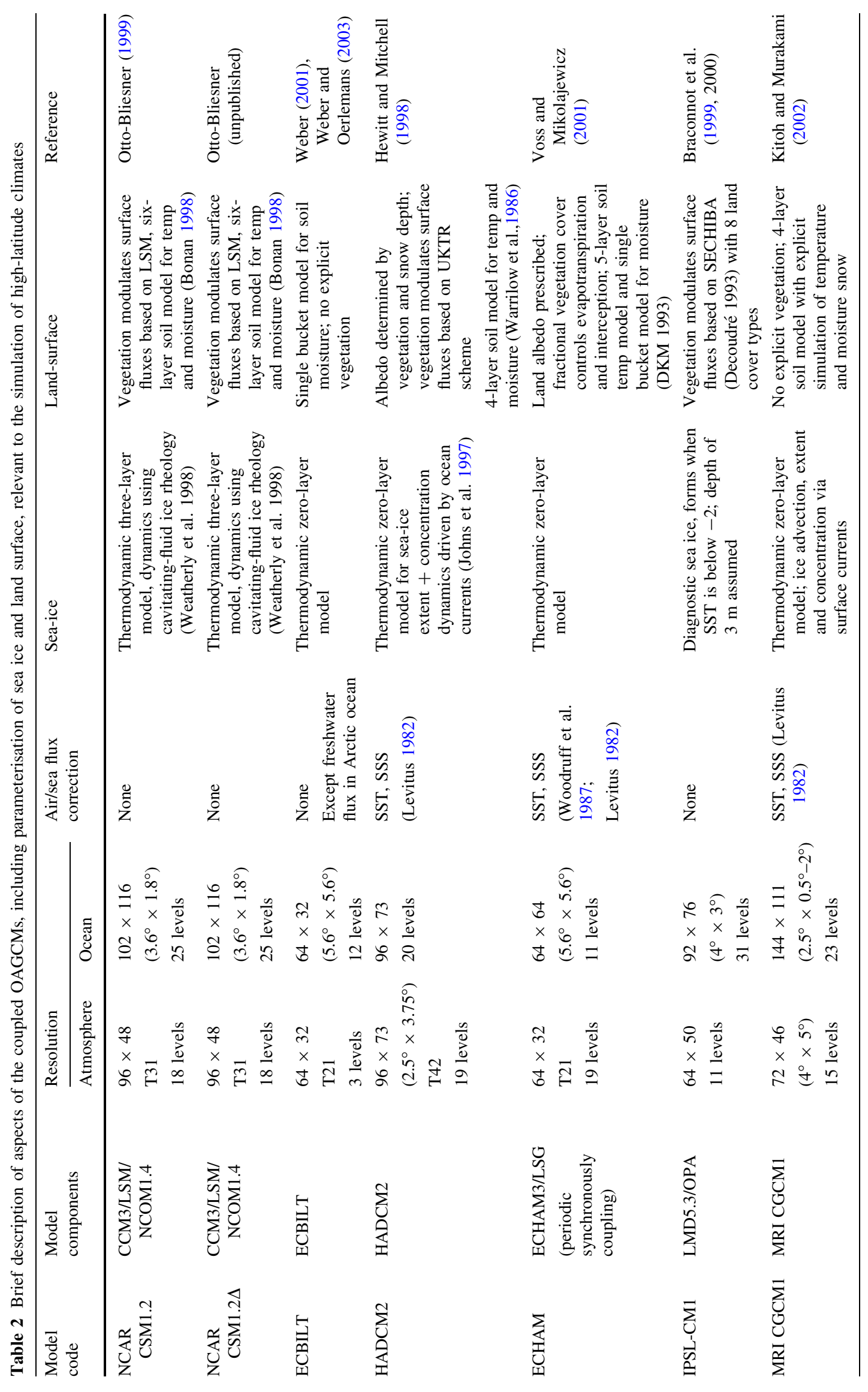


of tundra vegetation. These biomes arise from the combination of 14 plant functional types (PFTs). The distribution of PFTs is described in terms of tolerance thresholds for cold, heat, chilling, sunshine and moisture requirements. Cold tolerance is expressed in terms of monthly minimum mean temperature of the coldest month. The chilling requirement is formulated in terms of the maximum mean temperature of the coldest month (MTCO). The heat requirement is expressed in terms of growing-degree-days (GDD) above a threshold of $5^{\circ} \mathrm{C}$ for trees or $0^{\circ} \mathrm{C}$ for nonwoody plants. The distinction between cool and warm grass/shrub is based on mean temperature of the warmest month (MTWA). The sunshine is expressed in terms of relative cloudiness. Moisture requirements are expressed in terms of limiting values of the ratio of actual to equilibrium evapotranspiration $(\alpha)$. In each grid cell, the model selects the set of PFTs which could exist in the given climate and a dominance criterion is applied. Biomes arise through combinations of dominant PFTs. BIOME4 differs from previous versions of the model because it explicitly simulates the coupled carbon- and water-flux cycles. This flux scheme determines the leaf area index (LAI) that maximises the net primary productivity (NPP). It is thus able to treat competition between PFTs as a function of relative net primary productivity (NPP), using an optimisation algorithm to calculate the maximum sustainable leaf area (LAI) of each PFT and the associated NPP.

Comparison of the simulated vegetation distribution across the high northern latitudes against field-based maps of vegetation, standard potential vegetation maps and against modern pollen surface samples shows that BIOME4 produces a reliable simulation of natural vegetation patterns (Kaplan et al. 2003; Bigelow et al. 2003). Simulated NPP values for individual biomes are similar to observed values.

For diagnostic purposes, BIOME4 was run using an anomaly procedure. BIOME4 could be run using climatemodel output directly. However, this would necessitate an evaluation of the simulated vegetation patterns in both the $6 \mathrm{ka}$ experiment and the control. The use of an anomaly procedure, in which the change in climate between two simulations is superimposed on a modern (observational) climatology, is designed to (a) minimise the impact of biases in the climate control simulation on the simulated vegetation change and (b) preserve the climate patterning due to sub-gridscale topography apparent in the modern climatology (see e.g. Harrison et al. 1998). The anomaly approach is therefore preferable for the diagnosis of the realism of the simulated changes in climate and vegetation. To apply this procedure, differences in the long-term averages of monthly mean precipitation, temperature and sunshine between the $6 \mathrm{ka}$ and the control experiment for each model were linearly interpolated to the $0.5^{\circ}$ grid of the
BIOME4 model and then added to a modern climatology (CLIMATE 2.2.: Kaplan et al. 2003). Soil properties were specified from a data set derived from the FAO global soils map (FAO 1995). BIOME4 is calibrated for a present $\left[\mathrm{CO}_{2}\right]$ concentration of $324 \mathrm{ppmv}$, and the $\left[\mathrm{CO}_{2}\right]$ in the diagnostic simulations was left unchanged at this value.

\subsection{Palaeovegetation data for $6 \mathrm{ka}$}

The Pan-Arctic Initiative (PAIN) has reconstructed vegetation patterns at $6 \pm 0.5 \mathrm{ka}$ across the high northern latitudes (north of $55^{\circ} \mathrm{N}$ ) based on pollen records from individual sites using a standard procedure based on allocation of pollen taxa to PFTs (Bigelow et al. 2003). This reconstruction represents the most extensive compilation of palaeovegetation data from the high northern latitudes currently available, and has the merit of using a classification scheme that was designed to be compatible with the scheme used in BIOME4. There are 493 sites in the PAIN 6 ka reconstruction. Reconstructions of vegetation patterns south of the PAIN window have been made as a part of the Palaeovegetation Mapping Project (BIOME 6000: Prentice and Webb 1998; Prentice et al. 2000). There are reconstructions of vegetation at $6 \mathrm{ka}$ from 757 sites between $40^{\circ}$ and $55^{\circ} \mathrm{N}$ in the BIOME 6000 data set (Prentice et al. 1996; Tarasov et al. 1998; Edwards et al. 2000; Williams et al. 2000). The BIOME 6000 data set does not discriminate different tundra types, but the classification of temperate and boreal forest types in the BIOME 6000 data set is compatible with the forest classification used in PAIN. Thus, the two data sets can be amalgamated without making adjustments to the biome designations. There are 1,250 sites in the combined data set for 6 ka (Fig. 1a). A total of 140 of these sites are not used in the data-model comparisons, either because the sites are poorly dated (DC $=7$ using the COHMAP dating control scheme: $\mathrm{Yu}$ and Harrison 1995) or lie along the coast, on islands or in inland lake areas where the BIOME4 model has sea, lakes and/or rivers and thus there is no simulated vegetation for comparison.

\subsection{Analytic approach}

In our comparisons of the simulated and observed vegetation response to $6 \mathrm{ka}$ climate changes, we focus on regional signals previously identified in an analysis of $6 \mathrm{ka}$ simulations made with the IPSL OAGCM (Wohlfahrt et al. 2004). Comparison with other OAGCM simulations enables us to determine whether these signals are robust or specific to the IPSL OAGCM. We then compare the simulated changes with palaeovegetation reconstructions to determine whether the signals are realistic, and whether some models produce more realistic patterns than others. 

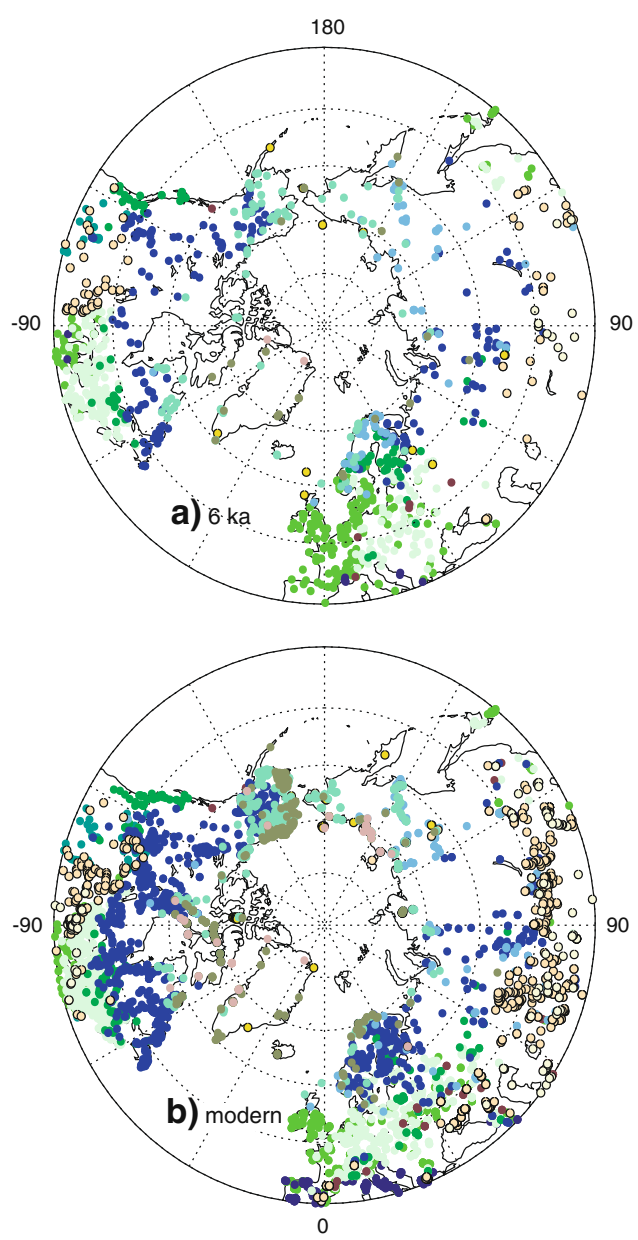

temperate deciduous broadleaf forest temperate evergreen needleleaf forest warm-temp. evergreen broadleaf \& mixed forest cool mixed forest

cool evergreen needleleaf forest cool-temp. evergr. needleleaf \& mixed forest cold evergreen needleleaf forest cold deciduous forest

Fig. 1 Pollen-based reconstructions of a $6 \mathrm{ka}$ and $\mathbf{b}$ modern vegetation patterns. The data from $40^{\circ} \mathrm{N}$ to $55^{\circ} \mathrm{N}$ are derived from Prentice et al. (2000), the data $\mathrm{N}$ of $55^{\circ} \mathrm{N}$ are derived from Bigelow et al. (2003)

To quantify the degree of agreement between simulated and observed vegetation patterns, we compare the reconstructed vegetation at each pollen site with the simulated vegetation in the $0.5^{\circ} \mathrm{BIOME}$ grid cell. When there is more than one pollen site in a $0.5^{\circ}$ grid cell, we use the vegetation type that is reconstructed most frequently on the assumption that this represents the dominant vegetation. We are concerned with climate signals that are relatively large and result in major changes in vegetation; for quantitative comparison purposes we therefore adopted a simplified biome classification scheme that groups individual biomes into major vegetation types (Harrison and
Prentice 2003). Thus our estimates of mismatches between the data and the simulations are relatively conservative.

\section{Results}

As a result of simulated changes in climate, all of the models produce changes in vegetation patterns compared to today (Fig. 2). However, there are differences in the nature and magnitude of regional vegetation changes between the simulations. Thus, the CSM1.2 $\Delta$ simulation produces a contraction of xerophytic vegetation in the western part of central North America that is not shown by the other models. Similarly, the IPSL-CM1 model produces a much larger northward migration of temperate deciduous forest than other models, such that the cool mixed forest belt in eastern North America is barely represented in this simulation.

\subsection{Impact of the length of averaging period} on simulated vegetation patterns

Differences between the models could reflect differences in the number of years averaged to construct the mean climate statistics used to drive the BIOME4 simulations. To assess how far this might be the case, we compare BIOME4 simulations based on a 20-year average from the IPSL-CM1 simulation (from year 80 to 100 : IPSL-CM1 $1_{20}$ ) and a 70 -year average (from year 80 to 150 : IPSL-CM1 $1_{70}$ ) from the same simulation (Table 3). The direction of change in vegetation is the same in both cases, although the magnitude of change in climate and the derived change in vegetation varies. Thus, both BIOME4 simulations show an increase in forest area at the expense of tundra, but the longer simulations show a smaller expansion of forest overall, reflecting the fact that the simulated mean summer warming is smaller. The difference in tundra area between the IPSL-CM1 $1_{20}$ and IPSL-CM1 $1_{70}$ runs is $2.57 \times 10^{5} \mathrm{~km}^{2}$ (equivalent to $20.5 \%$ of the change between 0 and $6 \mathrm{ka}$ in the IPSL-CM1 $1_{70}$ ). Both BIOME4 simulations show an increase in xerophytic vegetation, but again the longer simulations show a smaller increase overall. The difference in the area of xerophytic vegetation between the IPSL$\mathrm{CM} 1_{20}$ and IPSL-CM1 $1_{70}$ run is $10.36 \times 10^{5} \mathrm{~km}^{2}$ (equivalent to $37 \%$ of the change between 0 and $6 \mathrm{ka}$ in the IPSL-CM1 $1_{70}$ simulation). The difference in the area of xerophytic vegetation between the two runs is greater in Eurasia than North America, due to the simulation of a larger decrease in precipitation in Eurasia than in North America. There are no differences in the extent of temperate forests between the two versions. This reflects the fact that the simulated temperature changes over eastern 

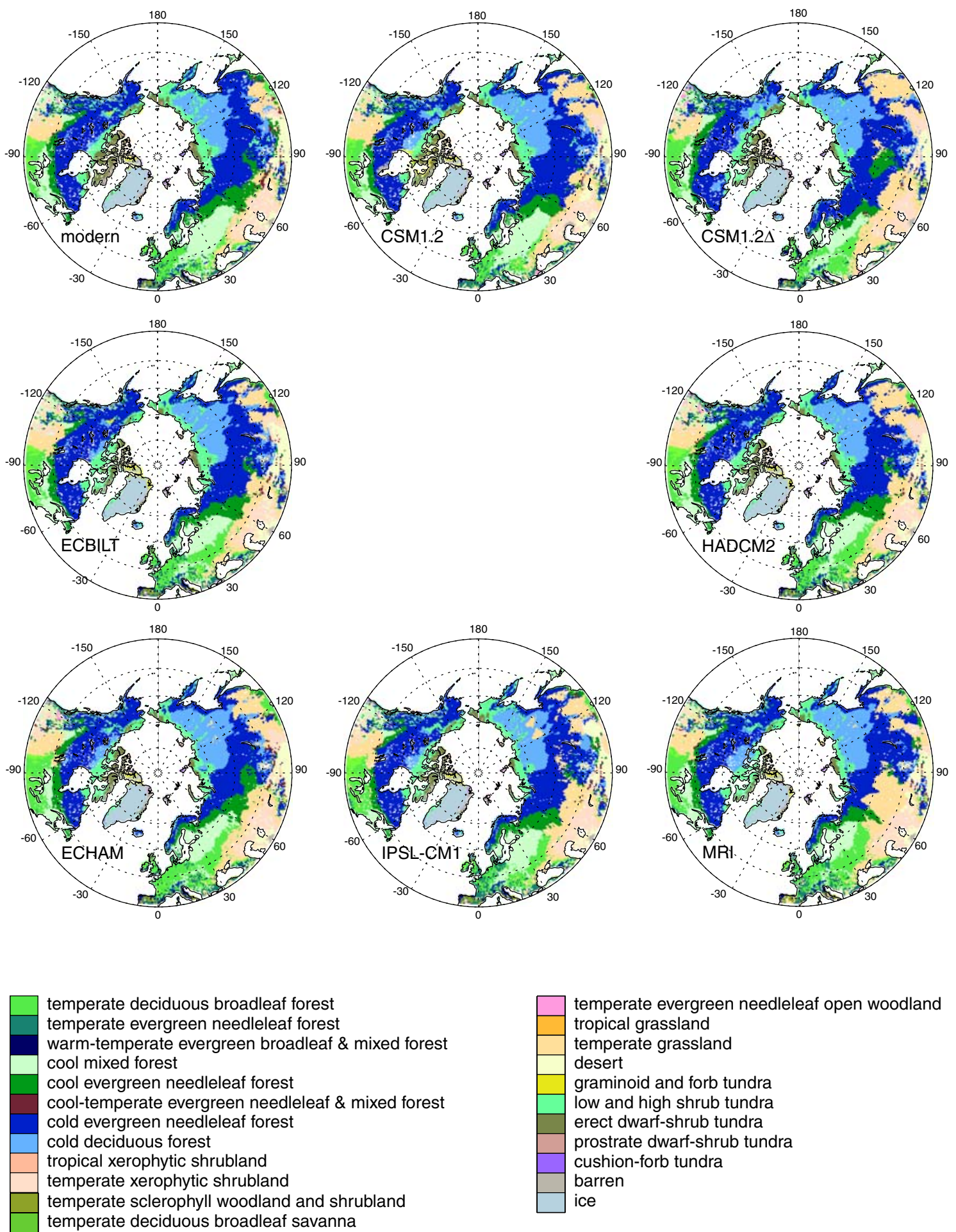

Fig. 2 Vegetation patterns at $6 \mathrm{ka}$ as simulated by BIOME4 driven by output from 7 OAGCM simulations. The modern vegetation map, simulated by BIOME4 driven by a modern climatology (CLIMATE 2.2), is shown for comparison

North America and Europe are very similar in the IPSL$\mathrm{CM} 1_{20}$ and IPSL-CM1 $1_{70}$ runs.

These comparisons show that the length of averaging period does not appear to affect the direction of the simulated vegetation changes. However, the magnitude of the simulated vegetation changes is generally less extreme when the climate average is based on a longer period of time. There does not appear to be any overall trend in the surface climate fields in the latter half of the IPSL simulation. We therefore assume that the 70-year average 
Table 3 Comparison of results from the IPSL-CM1 model based on 20 years of simulation and 70 years of simulation

\begin{tabular}{|c|c|c|}
\hline Region & $\begin{array}{l}\text { IPSL- } \\
\mathrm{CM}_{70}\end{array}$ & $\begin{array}{l}\text { IPSL- } \\
\mathrm{CM}_{20}\end{array}$ \\
\hline \multicolumn{3}{|l|}{$\mathrm{N}$ of $40^{\circ} \mathrm{N}$} \\
\hline$\Delta$ area tundra $\left(10^{5} \mathrm{~km}^{2}\right)$ & -12.53 & -15.1 \\
\hline$\Delta$ area forest $\left(10^{5} \mathrm{~km}^{2}\right)$ & -15.59 & -22.13 \\
\hline$\Delta T\left({ }^{\circ} \mathrm{C}\right)$ mean summer $(\mathrm{JJA})$ & 1.27 & 1.36 \\
\hline \multicolumn{3}{|l|}{ North America } \\
\hline \multicolumn{3}{|l|}{$90-120^{\circ} \mathrm{W}, 40-55^{\circ} \mathrm{N}$} \\
\hline$\Delta$ area xerophytic vegetation $\left(10^{5} \mathrm{~km}^{2}\right)$ & 4.36 & 5.2 \\
\hline$\Delta P(\mathrm{~mm} / \mathrm{d})$ mean summer $(\mathrm{JJA})$ & 0.00 & 0.02 \\
\hline \multicolumn{3}{|l|}{$90-120^{\circ} \mathrm{W}, 40-55^{\circ} \mathrm{N}$} \\
\hline $\begin{array}{l}\begin{array}{l}\Delta \text { area temperate deciduous broadleaf forest } \\
\left(10^{5} \mathrm{~km}^{2}\right)\end{array}\end{array}$ & 3.68 & 3.68 \\
\hline$\Delta T\left({ }^{\circ} \mathrm{C}\right)$ mean winter $(\mathrm{DJF})$ & -0.26 & -0.22 \\
\hline \multicolumn{3}{|l|}{ Eurasia } \\
\hline \multicolumn{3}{|l|}{$70-140^{\circ} \mathrm{E}, 40-60^{\circ} \mathrm{N}$} \\
\hline$\Delta$ area xerophytic vegetation $\left(10^{5} \mathrm{~km}^{2}\right)$ & 14.90 & 21.17 \\
\hline$\Delta P(\mathrm{~mm} / \mathrm{d})$ mean summer $(\mathrm{JJA})$ & -0.16 & -0.21 \\
\hline \multicolumn{3}{|l|}{ Europe } \\
\hline \multicolumn{3}{|l|}{$10^{\circ} \mathrm{W}-30^{\circ} \mathrm{E}, 40^{\circ}-60^{\circ} \mathrm{N}$} \\
\hline $\begin{array}{l}\Delta \text { area temperate deciduous broadleaf forest } \\
\left(10^{5} \mathrm{~km}^{2}\right)\end{array}$ & -0.78 & -0.78 \\
\hline$\Delta T\left({ }^{\circ} \mathrm{C}\right)$ mean winter $(\mathrm{DJF})$ & -0.31 & -0.35 \\
\hline
\end{tabular}

represents the mean climate better by filtering out the impact of interannual to decadal variability. Our diagnosis of the differences between models could be affected by differences in the length of time used to create climate averages from each of the model runs (Table 1), which in turn could influence the degree to which averages from the different models represent significant changes in mean climate or sampling of different states in short-term variability. Since we have no way of assessing this directly, we use the differences between IPSL-CM1 $1_{20}$ and IPSL-CM1 $1_{70}$ as a guide to whether inter-model differences in simulated biomes are likely to be significant.

\subsection{Shifts in the tundra-taiga boundary}

All of the models produce a northward shift in the position of the tundra-taiga boundary (Fig. 2). This shift results in a decrease in the area of tundra by between $9 \times 10^{5}$ and $34.9 \times 10^{5} \mathrm{~km}^{2}$ depending on the model, compared to present (Fig. 3, Table 4). The decrease in tundra area is markedly asymmetric, with most of the reduction occurring in Eurasia with $6.2-12.8 \times 10^{5} \mathrm{~km}^{2}(6.5-13.6 \%)$ and a smaller reduction in North America with $0.7-6.2 \times 10^{5} \mathrm{~km}^{2}$ (1.4-11.9\%). The shift of forest into areas that are tundra today results in an increase in the total area of forest north

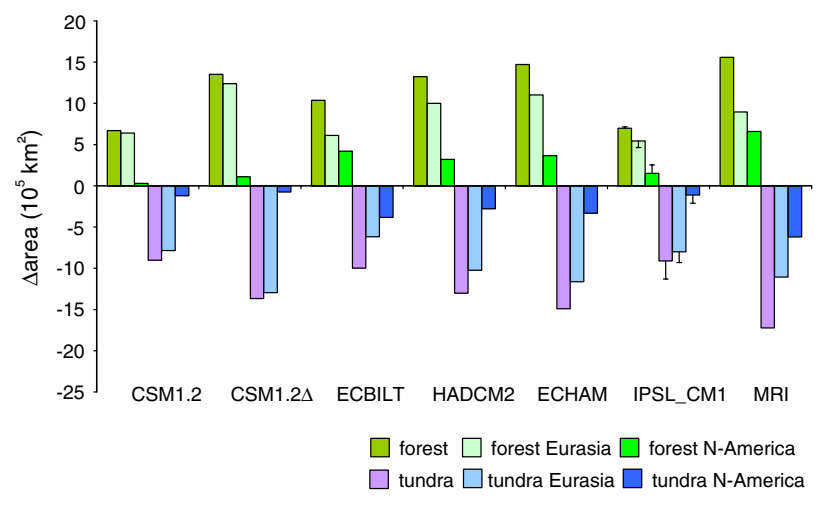

Fig. 3 Simulated changes in the area of tundra and forest north of $60^{\circ} \mathrm{N}$. The changes are also shown for Eurasia $\left(10^{\circ} \mathrm{W}-170^{\circ} \mathrm{W}\right)$ and North America $\left(170^{\circ} \mathrm{W}-10^{\circ} \mathrm{W}\right)$ separately. The error bars show the difference between the IPSL-CM1 20 and IPSL-CM1 $1_{70}$ simulations

of $60^{\circ} \mathrm{N}$ (Fig. 3). Using the difference between the IPSL$\mathrm{CM}_{20}$ and IPSL-CM1 $1_{70}$ results as a guideline, the differences in the size of the reduction in tundra area between the models are relatively small. Only the MRI simulation produces changes that appear to be larger than the other models.

The decreased extent of tundra at $6 \mathrm{ka}$ is a consequence of changes in the length of the growing season: simulated GDD is much higher at $6 \mathrm{ka}$ than today. The increase in GDD is driven by higher temperatures during the summer and autumn (Fig. 4). The change in summer and autumn (June through September) temperatures explains $42 \%$ of the inter-model variation in the change in tundra area in Eurasia, and $67 \%$ of the variation in the change in tundra in North America. The increase in summer temperatures is a direct consequence of the orbitally forced increase in high latitude insolation, the prolongation of warm conditions into the autumn is caused by ocean feedbacks.

The northward shift of the tundra-taiga boundary and the asymmetry of this shift, with largest changes in Europe and Central Siberia, are qualitatively in agreement with palaeoenvironmental observations (compare Fig. 1 with Fig. 2). Quantitative comparisons between the simulated vegetation changes and the combined PAIN-BIOME6000 data set (Fig. 5) show that the models produce a relatively good match $(67-70 \%)$ to observations in North America. Analyses of the mismatched sites show that the models consistently predict more forest than observed. Most of the errors occur in eastern Canada, where the observations suggest that tundra was further south than today at $6 \mathrm{ka}$ but the simulations show a northward shift in forest. The failure to simulate southward expansion of tundra probably reflects the fact that the models do not include the relict Laurentide ice sheet which persisted in Quebec as late as 5,000 years B.P. and resulted in a localised cooling (Clark et al. 2000; Marshall et al. 2000). The quantitative match to 
Table 4 Area of biomes and major biomes simulated by each of the OAGCMs in the northern hemisphere extratropics (north of $40^{\circ} \mathrm{N}$ ) compared to the modern area in $10^{5} \mathrm{~km}^{2}$

\begin{tabular}{|c|c|c|c|c|c|c|c|c|}
\hline Biome name & Modern & CSM1.2 & CSM1.2A & ECBILT & HADCM2 & ECHAM & IPSL-CM1 70 & MRI \\
\hline Temperate deciduous broadleaf forest & 24.03 & 23.9 & 32.31 & 33.6 & 33.57 & 42.17 & 29.85 & 40.29 \\
\hline Temperate evergreen needleleaf forest & 7.07 & 7.76 & 6.32 & 8.23 & 8.47 & 8.58 & 10.53 & 9.03 \\
\hline Warm-temperate evergreen broadleaf mixed forest & 2.51 & 1.09 & 2.65 & 2.37 & 2.31 & 2.97 & 2.1 & 2.01 \\
\hline Cool mixed forest & 45.83 & 38.52 & 30.44 & 35.51 & 37.86 & 36.73 & 33.64 & 29.66 \\
\hline Cool evergreen needleleaf forest & 39.48 & 27.62 & 31.85 & 33.17 & 33.76 & 36.8 & 30.28 & 28.95 \\
\hline Cool-temperate evergreen needleleaf mixed forest & 4.82 & 2.45 & 2.09 & 3.47 & 3.17 & 4.14 & 3.15 & 3 \\
\hline Cold evergreen needleleaf forest & 133.85 & 134.83 & 133.67 & 134.04 & 126.03 & 111.73 & 129.84 & 121.6 \\
\hline Cold deciduous forest & 40 & 51.77 & 53.15 & 42.77 & 43.2 & 50.91 & 42.62 & 50.89 \\
\hline All forest & 297.61 & 287.95 & 292.49 & 293.16 & 288.37 & 294.03 & 282.02 & 285.43 \\
\hline Temperate xerophytic shrubland & 20.68 & 17.88 & 22.07 & 21.5 & 24.17 & 23.99 & 22.31 & 22.31 \\
\hline Temperate sclerophyll wood and shrubland & 1.94 & 0.71 & 1.57 & 2.35 & 2.23 & 2.12 & 2.32 & 2.28 \\
\hline Temperate deciduous broadleaf savanna & 4.66 & 3.19 & 2.03 & 4.25 & 5.12 & 4.98 & 5.46 & 2.47 \\
\hline Temperate evergreen needleleaf open woodland & 0.87 & 1.01 & 1.74 & 0.95 & 1.29 & 1.1 & 0.99 & 0.44 \\
\hline Temperate grassland & 31.38 & 52.14 & 64.17 & 46.23 & 54.86 & 52.08 & 56.25 & 67.43 \\
\hline All xerophytic vegetation & $\mathbf{5 9 . 5 5}$ & 74.94 & 91.58 & 75.29 & 87.7 & 84.31 & 87.38 & 94.96 \\
\hline Graminoid and forb tundra & 2.27 & 5.18 & 1.1 & 3.06 & 2.24 & 1.95 & 1.8 & 2.36 \\
\hline Low and high shrub tundra & 42.25 & 33.18 & 31.64 & 39.29 & 33.08 & 33 & 38.22 & 34.16 \\
\hline Erect dwarf-shrub tundra & 19.86 & 15.92 & 14.55 & 11.95 & 13.29 & 12.13 & 14.02 & 9.51 \\
\hline Prostrate dwarf-shrub tundra & 4.02 & 2.69 & 3.27 & 1.63 & 2.61 & 2.83 & 2.74 & 1.82 \\
\hline Cushion-forb tundra & 1.63 & 1.6 & 0.91 & 0.61 & 0.89 & 0.83 & 0.71 & 0.82 \\
\hline All tundra & 70.02 & 58.57 & 51.48 & 56.54 & 52.11 & 50.74 & 57.49 & 48.68 \\
\hline Desert & 14.63 & 13.47 & 7.43 & 17.33 & 14.54 & 13.89 & 16.04 & 13.64 \\
\hline Barren & 2.41 & 9.28 & 1.23 & 1.88 & 1.48 & 1.23 & 1.28 & 1.5 \\
\hline
\end{tabular}

observations in Eurasia is better (77-83\%) than over North America. Furthermore, there is no consistent pattern to the individual mismatches: neither forest nor tundra is consistently over-represented in the simulations.

\subsection{Mid-continental expansion of xerophytic vegetation}

All of the models produce an expansion of xerophytic vegetation (e.g. tropical/temperate shrubland, tropical/ temperate grassland, temperate sclerophyll woodlands/savannahs, and desert) in the mid-continental regions of the northern hemisphere (Fig. 2). The area of xerophytic vegetation in the mid-latitudes (Table 4) increases by 15.4$35.4 \times 10^{5} \mathrm{~km}^{2}$, with most of the increase (11.1-19.9 $\times$ $\left.10^{5} \mathrm{~km}^{2}\right)$ being in Eurasia $\left(70-140^{\circ} \mathrm{E}, 40-60^{\circ} \mathrm{N}\right)$ and particularly east of $100^{\circ} \mathrm{E}$ in Asia $\left(5.3-12.8 \times 10^{5} \mathrm{~km}^{2}\right)$. The expansion of xerophytic vegetation in Eurasia resulted in a decrease in the area of temperate and boreal forests (Fig. 6). The largest changes in the area of mid-latitude xerophytic vegetation are shown by the MRI and HADCM2 model and the CSM1.2A simulation. Most of the models show an expansion of xerophytic vegetation in North America, but this expansion was relatively small $\left(0.8-4.4 \times 10^{5} \mathrm{~km}^{2}\right)$ and confined to the western part of the continent. Surprisingly the two simulations with largest overall increase in xerophytic vegetation show smallest changes in western North America. The CSM model simulation in which $\left[\mathrm{CO}_{2}\right]$ was lowered at $6 \mathrm{ka}$, however, shows a small decrease in xerophytic vegetation. With this exception, the inter-model differences in the magnitude of the expansion of xerophytic vegetation are small. Using the difference between the IPSL-CM1 $1_{20}$ and IPSL-CM1 $1_{70}$ results as a guideline; all models produce a similar expansion of dry xerophytic vegetation in the midcontinents.

The increased extent of xerophytic vegetation at $6 \mathrm{ka}$ is necessarily a consequence of decreased plant-available moisture (PAM) during the growing season. Inter-model differences in the change in area of xerophytic vegetation in western North America are indeed strongly correlated $\left(R^{2}=0.83\right)$ with changes in summer precipitation (Fig. 8c). In Eurasia, however, most of the models show an increase in summer precipitation (Fig. 7a). In earlier 


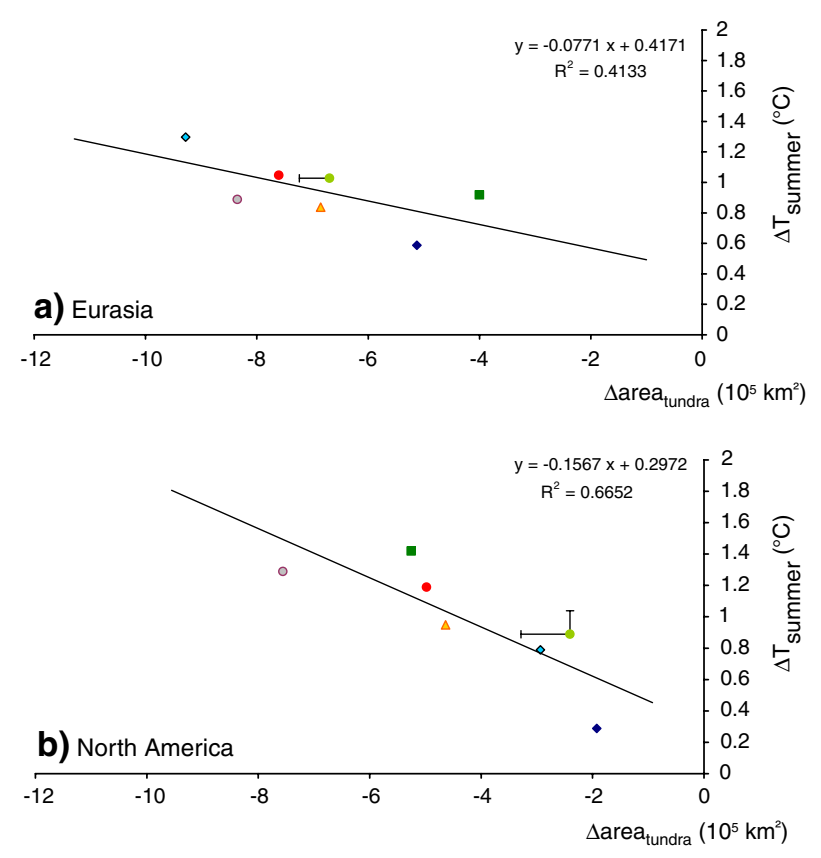

$\bullet$ CSM $1.2 \diamond$ CSM $1.2 \Delta \square$ ECBILT $\triangle$ HADCM2 $\bullet$ ECHAM $\bigcirc$ IPSL_CM1 O MRI

Fig. 4 Comparison of simulated changes in the area of tundra and changes in mean summer (June, July, August, September) temperature. The comparisons are made for a Eurasia $\left(10^{\circ} \mathrm{W}-170^{\circ} \mathrm{W}\right)$ and b North America $\left(170^{\circ} \mathrm{W}-10^{\circ} \mathrm{W}\right)$ separately. The southern boundary for these comparisons is taken at $65^{\circ} \mathrm{N}$ for Eurasia and $55^{\circ} \mathrm{N}$ for North America so as to encompass the different location of the taiga-tundra boundary on each continent. The error bars show the difference between the IPSL-CM1 $1_{20}$ and IPSL-CM1 $1_{70}$ simulations

analyses of the expansion of xerophytic vegetation in the IPSL simulation (Wohlfahrt et al. 2004), the simulated decrease in PAM was driven by a decrease in precipitation during the spring, summer and autumn (Fig. 7, lower panels). Only ECBILT shows this pattern of decreased precipitation during the whole of the growing season, although most of the models show a decrease in spring precipitation over Eurasia. However, the decrease in spring precipitation alone is not sufficient to explain the intermodel differences in the expansion of xerophytic vegetation in this region. Although the magnitude of the change in xerophytic vegetation cannot be explained by precipitation changes (Fig. 8a), there is a strong positive correlation $\left(R^{2}=0.80\right)$ between the change in the area of xerophytic vegetation and summer (June through August) temperatures over Eurasia (Fig. 8b). There is a similar relationship $\left(R^{2}=0.70\right)$ between the change in xerophytic vegetation and summer temperatures over western North America (Fig. 8d). These results imply that the expansion of xerophytic vegetation is controlled by temperature-driven increases in evapotranspiration rather than any change in precipitation, although clearly decreases in precipitation may contribute to the decrease in PAM in the case of individual models.

\section{a) North America}

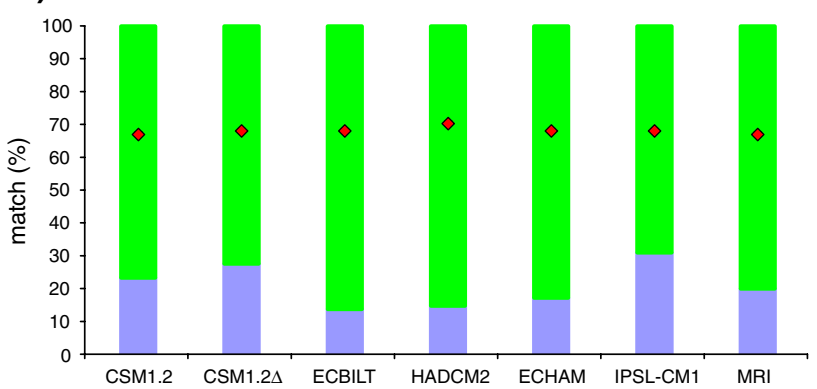

\section{b) Eurasia}

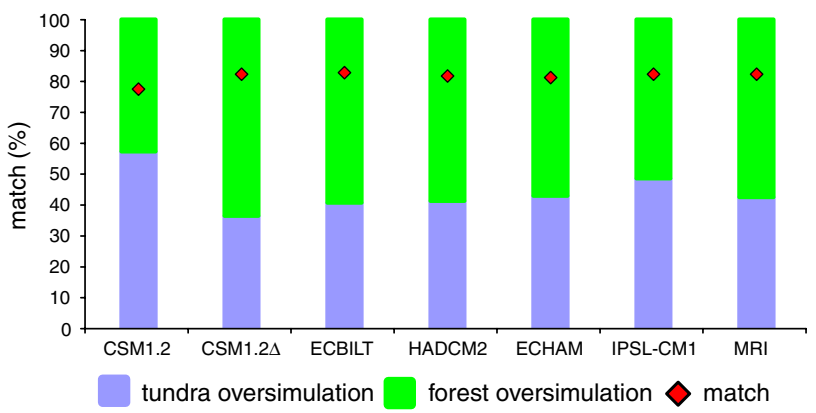

Fig. 5 Comparison of observed and simulated changes in the tundrataiga boundary in a North America $\left(170^{\circ} \mathrm{W}-10^{\circ} \mathrm{W}, \mathrm{N}\right.$ of $\left.55^{\circ} \mathrm{N}\right)$ and $\mathbf{b}$ Eurasia $\left(10^{\circ} \mathrm{W}-170^{\circ} \mathrm{W}, \mathrm{N}\right.$ of $\left.65^{\circ} \mathrm{N}\right)$. The red diamonds show the overall match $(\%)$ between observed and simulated changes for each model. The stacked bars show the relative proportion of the mismatches that are due to simulation of forest in areas where the observed vegetation was tundra (forest oversimulation) or the simulation of tundra in areas where the observed vegetation was forest (tundra oversimulation). Differences between the two IPSL-CM simulations are negligible

The expansion of xerophytic vegetation in western North America is qualitatively in agreement with palaeoenvironmental observations (Harrison et al. 2003; compare Figs. 1, 2). Quantitative comparisons with the combined PAIN-BIOME6000 data set (Fig. 9) show that the models produce a relatively good match (66-77\%) to observations.

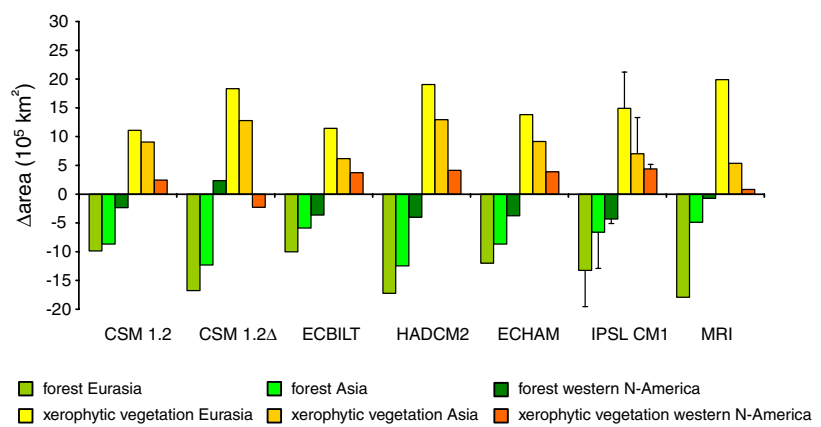

Fig. 6 Simulated changes in xerophytic vegetation and forest in $10^{5} \mathrm{~km}^{2}$ for mid-continental Eurasia $\left(70-140^{\circ} \mathrm{E}, 40-60^{\circ} \mathrm{N}\right)$, the core region Asia $\left(100-140^{\circ} \mathrm{E}, 40-60^{\circ} \mathrm{N}\right)$ and western North America $(90$ $\left.120^{\circ} \mathrm{W}, 40-55^{\circ} \mathrm{N}\right)$. The error bars show the difference between the IPSL-CM1 20 and IPSL-CM1 $1_{70}$ simulations 
Fig. 7 Changes in seasonal cycle of temperature and precipitation for a Eurasia (70$140^{\circ} \mathrm{E}, 40-60^{\circ} \mathrm{N}$ ) and $\mathbf{b}$ western North America $\left(90-120^{\circ} \mathrm{W}, 40\right.$ $55^{\circ} \mathrm{N}$ ) as simulated by each OAGCM. The results of the IPSL-CM1 $1_{20}$ simulation for temperature and precipitation are shown by light green bars and a line, respectively

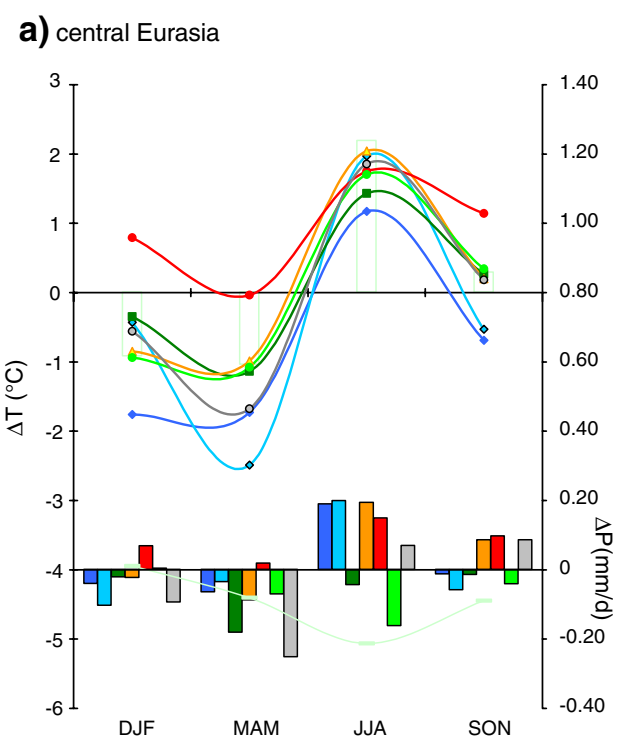

b) western N-America

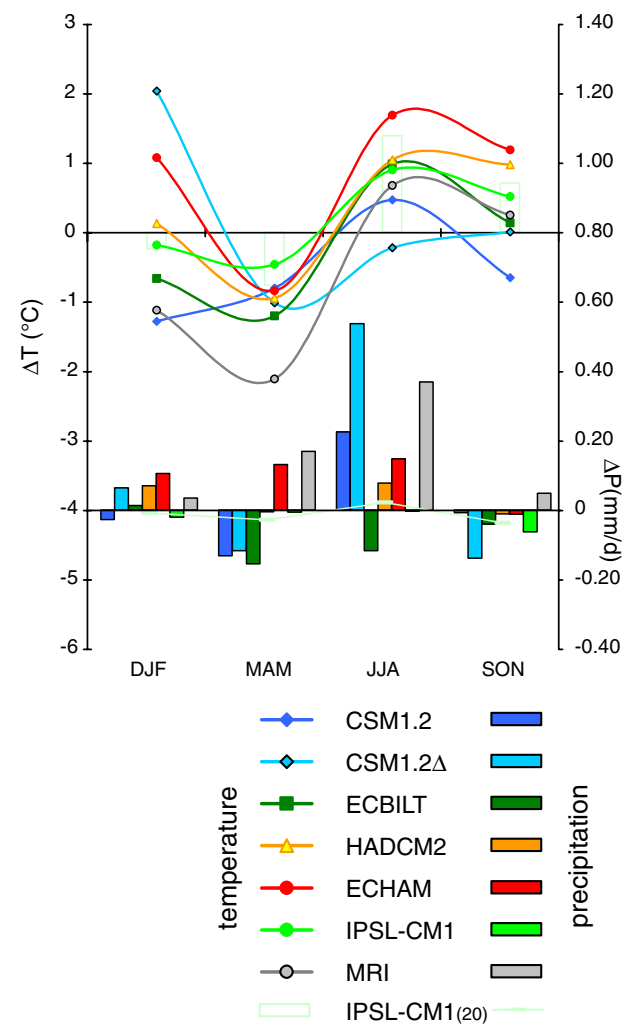

C) western N-America (Psummer)
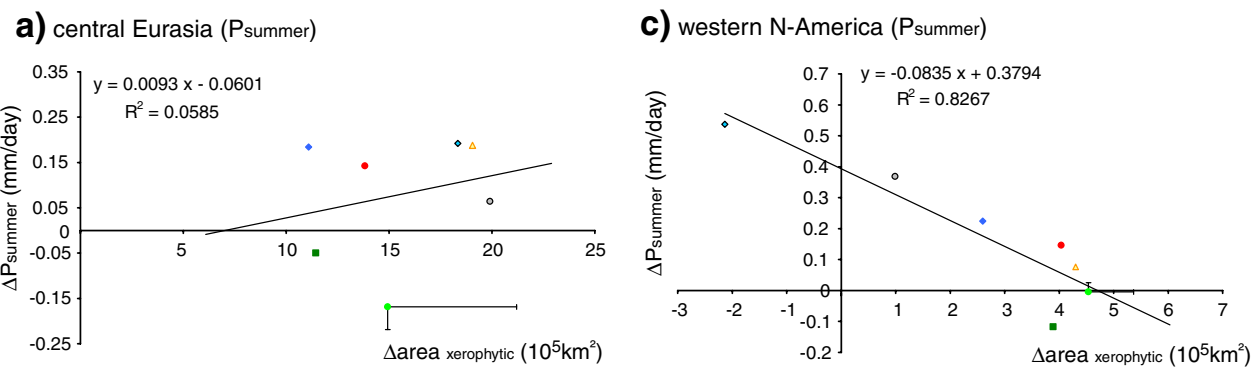

b) central Eurasia (Tsummer)

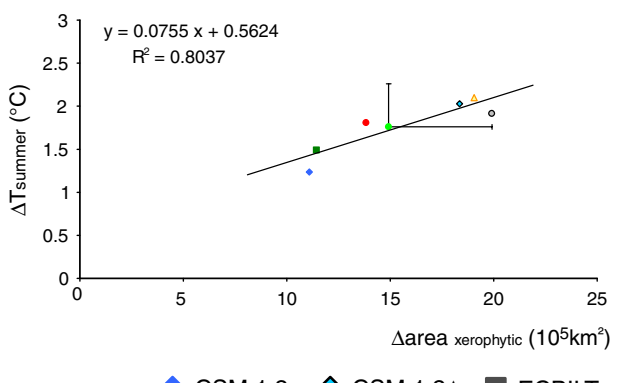

d) western N-America (Tsummer)

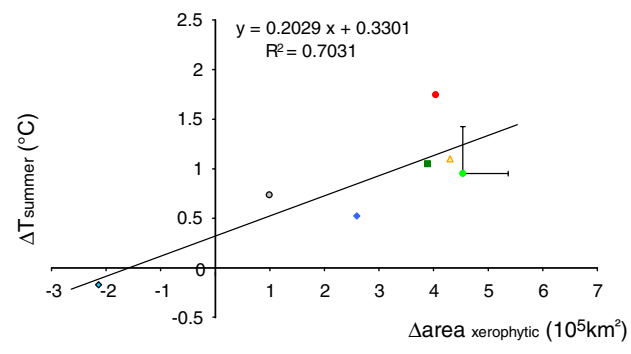

CSM $1.2 \diamond \operatorname{CSM} 1.2 \Delta$

ECHAM IPSL_CM1 O MRI
Analyses of the mismatched sites show that there is a tendency for the models to overestimate the amount of forest present compared to observations. There is a significantly poorer match between the simulated and observed vegetation patterns in Eurasia (42-65\%). Analyses of the mismatched sites show that the models consistently over-predict the extent of xerophytic vegetation in the Asian sector (Fig. 9b). 
a) central Eurasia

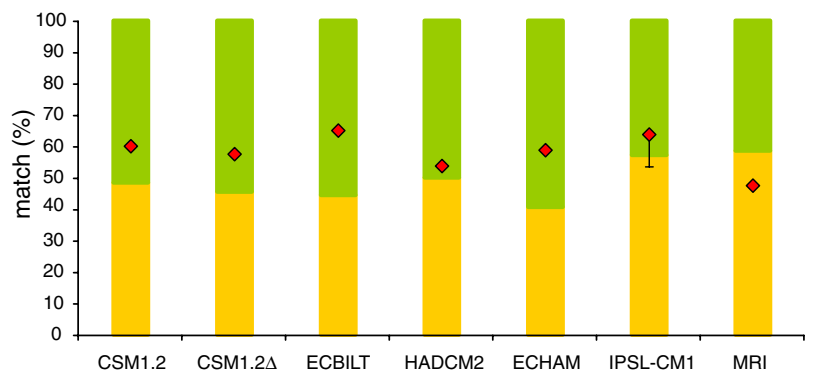

b) Asia

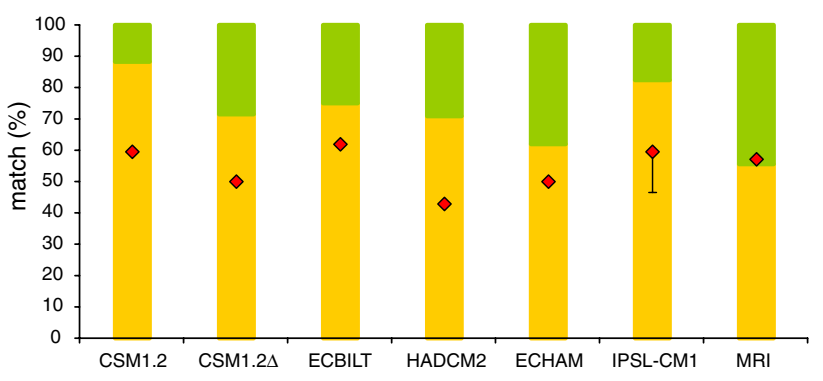

c) western North-America

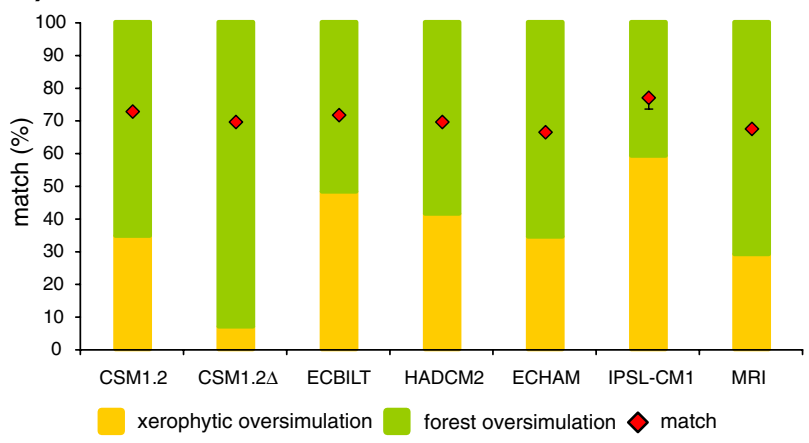

Fig. 9 Comparison of observed and simulated changes in xerophytic and forest vegetation in the mid-continent regions of a Eurasia (70$\left.140^{\circ} \mathrm{E}, 40-60^{\circ} \mathrm{N}\right)$, b the core region of Asia $\left(100-140^{\circ} \mathrm{E}, 40-60^{\circ} \mathrm{N}\right)$ and c western North America $\left(90-120^{\circ} \mathrm{W}, 40-55^{\circ} \mathrm{N}\right)$. The red diamonds show the overall match $(\%)$ between observation and simulated changes for each model. The stacked bars show the relative proportion of the mismatches that are due to simulation of forest in areas where the observed vegetation was xerophytic (forest oversimulation) or the simulation of xerophytic in areas where the observed vegetation was forest (xerophytic oversimulation). The error bar shows the difference between the IPSL-CM1 $1_{20}$ and IPSL-CM1 $1_{70}$ simulations

\subsection{Shifts in the temperate forests of eastern North America}

All of the models produce a small northward expansion of the temperate deciduous broadleaf forests in eastern North America (Fig. 2). The area of temperate deciduous broadleaf forest in the zone from $40^{\circ}$ to $55^{\circ} \mathrm{N}$ increases by $0.7-$ $3.7 \times 10^{5} \mathrm{~km}^{2}(16-80 \%)$, generally at the expense of cold forest types (Fig. 10a) although in the case of CSM1.2, CSM1.2 $\Delta$, ECBILT, and IPSL-CM1 the increase in
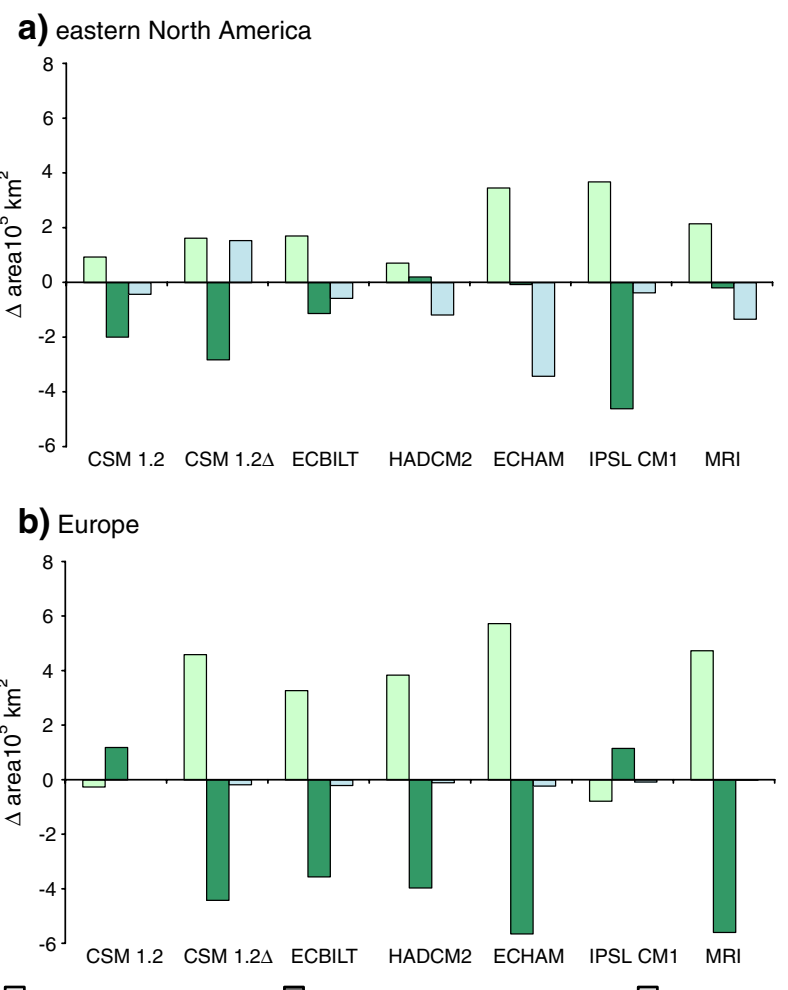

$\square$ temp deciduous broadleaf forest $\square$ temp and cool evergreen and mixed forest $\square$ cold boreal forest

Fig. 10 Simulated changes in the area of the main forest types in a eastern North America $\left(60-90^{\circ} \mathrm{W}, 40-55^{\circ} \mathrm{N}\right)$ and b Europe $\left(10^{\circ} \mathrm{W}-\right.$ $\left.30^{\circ} \mathrm{E}, 40-60^{\circ} \mathrm{N}\right)$. The changes in the temperate deciduous broadleaf forest are shown relative to changes in temperate and cool evergreen and mixed forest grouping the biomes types of temperate evergreen needleleaf forest, cool-temperate evergreen needleleaf mixed forest, cool mixed forest and cool evergreen needleleaf forest and cold boreal forest, combining cold evergreen needleleaf forest and cold deciduous forest. Differences between the two IPSL-CM simulations are negligible

temperate deciduous broadleaf forest also occurs as a result of the decrease in temperate and cool evergreen and mixed forest. The increase of temperate deciduous broadleaf forest and cool-temperate mixed forest in the HADCM2 simulation is related to the decrease and northward shift of boreal forest. In the case of the CSM and IPSL simulations the decrease in cool-temperate mixed forest is larger than can be accounted for by the expansion of temperate deciduous broadleaf forest, and is partly due to encroachment by non-forest types. The expansion of temperate forests is a result of winter warming. However, because the changes are relatively small and occur in discrete patches (rather than as a shift of a zonal boundary across the region) it is difficult to show a strong statistical relationship between the simulated climate and biome changes.

The northward shift of the temperate deciduous broadleaf forest is consistent with observations (Fig. 11a). Quantitative comparisons between the simulated vegetation changes and the combined PAIN-BIOME6000 data 
Fig. 11 Observed changes in the latitudinal distribution of warm-temperate evergreen broadleaf forest, temperate deciduous broadleaf forest, cool mixed forest and cool evergreen needleleaf forest 0 and $6 \mathrm{ka}$ in $\mathbf{a}$ eastern North America (60$\left.90^{\circ} \mathrm{W}, 40-55^{\circ} \mathrm{N}\right)$ and b Europe $\left(10^{\circ} \mathrm{W}-30^{\circ} \mathrm{E}, 40-60^{\circ} \mathrm{N}\right)$
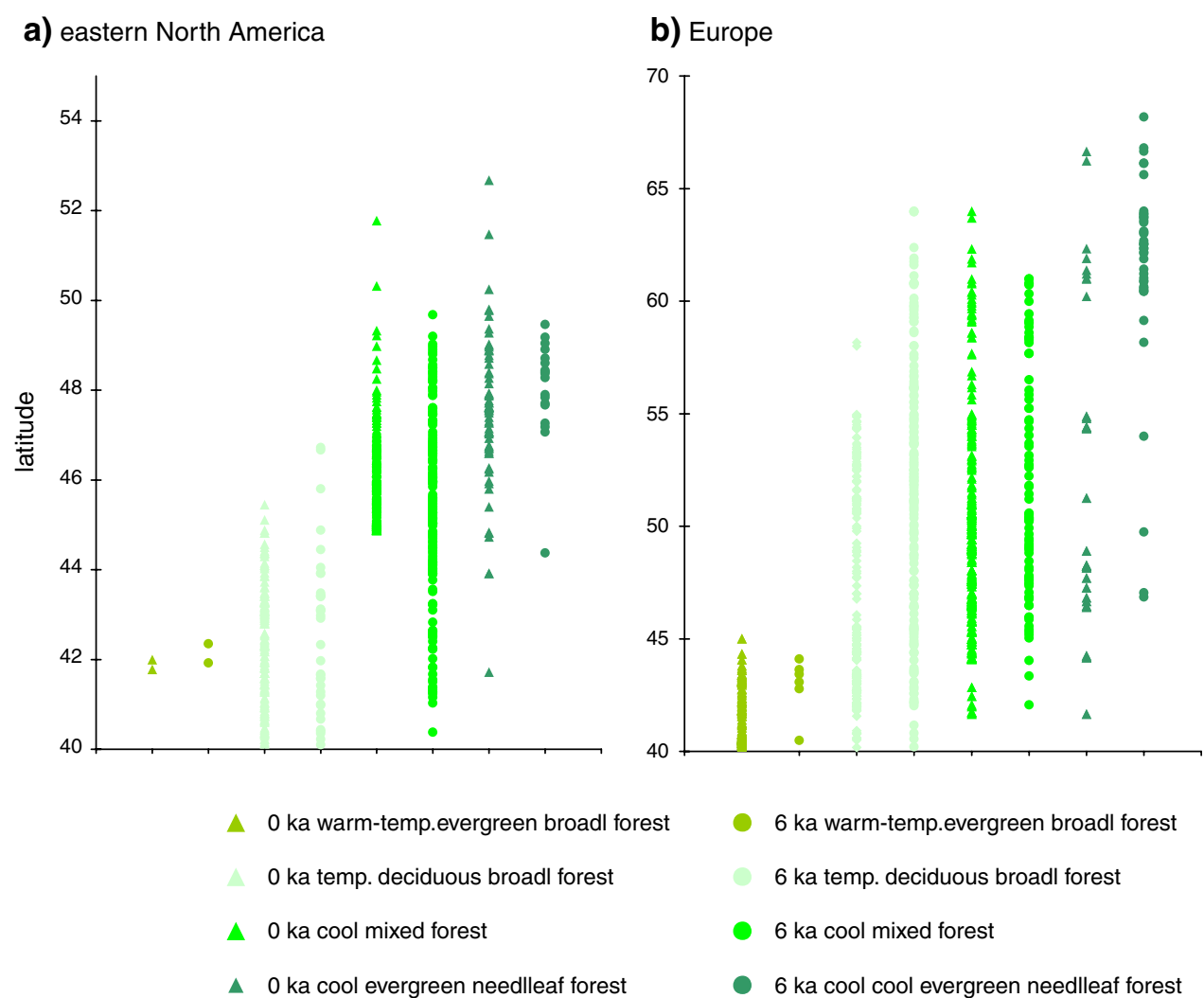

set (Fig. 12a) show that the match to the data varies considerably from model to model: the worst match $(42.7 \%)$ to the observations is produced by the IPSL simulation and the best match $(75.5 \%)$ by the CSM simulation. However, analyses of the mismatched sites (Fig. 12a) show that all of the models tend to predict forest types characteristic of warmer conditions than observed. The observed expansion of temperate forests in the northern part of this region was probably limited by regional cooling due to the presence of the relict Laurentide ice sheet (Clark et al. 2000; Marshall et al. 2000).

\subsection{Shifts in the temperate forests of Europe}

The simulated changes in temperate forest belts in Europe are not consistent from model to model (Fig. 2). Five of the models show an increase in temperate deciduous broadleaf forest, in response to the simulation of warmer winters. In the case of the ECBILT and MRI models, this warming appears to be highly localised and does not register in regional averages. In contrast, two of the models (CSM and IPSL) produce a decrease in temperate deciduous broadleaf forest, in response to the simulation of colder winters.

Observations show that the northern boundary of the temperate deciduous broadleaf forest in Europe was much further north at $6 \mathrm{ka}$ than it is today (Fig. 11b). Thus, the models that produce a northward shift in the northern boundary of this forest type are qualitatively correct. However, quantitative comparison of the simulated changes indicates that even these models only produce a moderate match (44-58\%) to the observations (Fig. 12b). Furthermore, analyses of the mismatches show that these models consistently underpredict the amount of temperate deciduous broadleaf forest, and thus that they must underpredict the magnitude of winter warming compared to the changes implied by the observations. IPSL and CSM, the two models which produce winter cooling, show the largest over-representation of cold forests at the expense of temperate deciduous broadleaf forest. The differences between model simulations, and the large discrepancies between model and data, suggest that coupled simulations do not produce a better simulation of the climate of western European region than PMIP AGCM simulations (Harrison et al. 1998; Guiot et al. 1999; Masson et al. 1999).

\subsection{The impact of changing $\left[\mathrm{CO}_{2}\right]$ on simulated vegetation patterns: CSM1.2 versus CSM1.2A}

The ECHAM 6 ka simulation differs from the ECHAM control simulation not only with respect to insolation forcing but also because the $6 \mathrm{ka} \mathrm{CO}_{2}$ level was lowered from $345 \mathrm{ppmv}$ (control) to $280 \mathrm{ppmv}$ (6 ka). It seems unlikely that this difference in experimental design is important as a factor giving rise to inter-model differences, 
a) eastern North America

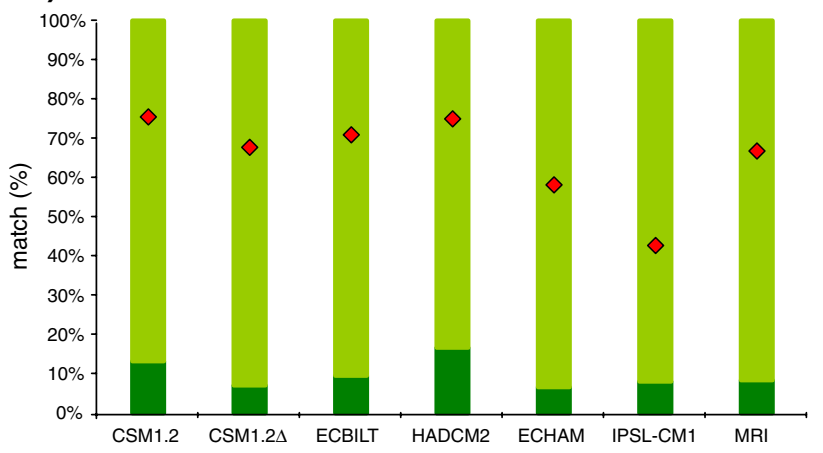

b) Europe

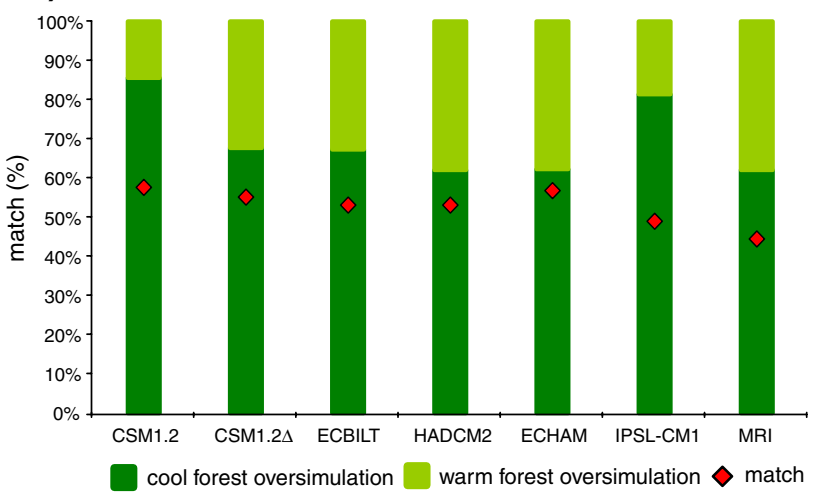

Fig. 12 Comparison of simulated and observed vegetation changes in a eastern North America $\left(60-90^{\circ} \mathrm{W}, 40-55^{\circ} \mathrm{N}\right)$ and $\mathbf{b}$ Europe $\left(10^{\circ} \mathrm{W}-\right.$ $\left.30^{\circ} \mathrm{E}, 40-60^{\circ} \mathrm{N}\right)$. The red diamonds show the overall match $(\%)$ between observation and simulated changes for each model. The stacked bars show the relative proportion of the mismatches that are due to simulation of wrong vegetation types. In areas where the observed vegetation was either temperate deciduous broadleaf forest or warm-temperate evergreen broadleaf forest and the simulations show cool mixed or cool evergreen needleleaf or cool-temperate evergreen needleleaf forests, then the mismatches are shown as "cool forest overestimation". Warm forest oversimulation implies errors in the opposite direction (i.e. temperate forests being simulated where cool forests occurred). Differences between the two IPSL-CM simulations are negligible

given that the ECHAM simulation shows the same broadscale changes as the other models and that the magnitude of the changes in key areas lies within the range shown by the other models (which have the same $\mathrm{CO}_{2}$ level in the control and $6 \mathrm{ka}$ experiment). Nevertheless, this difference in experimental design raises the issue of how changing $\mathrm{CO}_{2}$ might impact the $6 \mathrm{ka}$ vegetation simulations, either directly (i.e. through affecting regional climate) or indirectly (i.e. through the effect on vegetation physiology: Harrison and Prentice 2003). We have examined this briefly by comparing two simulations made with the CSM1.2 model. In the first set of simulations (CSM1.2), there is no change in $\mathrm{CO}_{2}$ between the control and $6 \mathrm{ka}$ simulations. In the second set of simulations (CSM1.2 $\Delta$ ), $\mathrm{CO}_{2}$ is lowered from $355 \mathrm{ppmv}$ in the control to $280 \mathrm{ppmv}$ at $6 \mathrm{ka}$.
Comparison of these simulations shows that changing $\left[\mathrm{CO}_{2}\right]$ has an impact on northern hemisphere vegetation patterns. The CSM1.2 $\Delta$ simulation shows a larger decrease in tundra area than the CSM1.2 run, predominantly in Europe (Fig. 3). This reflects the fact that the change in summer temperature (Fig. 4) in the CSM1.2A run is approximately double the change in the CSM1.2 run. In the mid-latitude continental regions, the CSM1.2A simulation produces a larger increase in xerophytic vegetation in Eurasia than the CSM1.2 but reduces the area of xerophytic vegetation in North America (Fig. 6). The reduction in the area of xerophytic vegetation in North America is a result of a large increase in summer precipitation and cooler summer temperatures (Fig. 7). In eastern North America, the CSM1.2A simulation produces enhanced winter warming compared to the CSM1.2 simulation in the south, allowing temperate deciduous broadleaf forest to expand in area (Fig. 10). Northward expansion of this forest belt is prevented, however, by the simulation of colder winters over eastern Canada in the CSM1.2A simulation, which in turn results in southward expansion of boreal and cool mixed forests (Fig. 2). Thus, much of the expansion in temperate deciduous forest is westward, into areas occupied by xerophytic vegetation in the standard CSM simulation. The $\left[\mathrm{CO}_{2}\right]$ lowering produces a radical change in the signal over Europe. In CSM1.2 the winters are colder, resulting in a small reduction of temperate deciduous broadleaf forest. In CSM1.2A, the temperate deciduous broadleaf forest expands in response to winter warming.

There are two factors which appear to influence the strength and nature of the response to lowering $\left[\mathrm{CO}_{2}\right]$. To some degree, the response appears to depend on the relative importance of the direct atmospheric response and ocean feedback in producing the change in regional climate. In those regions where the atmospheric response is strong, lowering $\left[\mathrm{CO}_{2}\right]$ produces colder (e.g. eastern North America) and drier (e.g. continental Eurasia) conditions as might be expected. However, when ocean feedback has a significant impact (e.g. Europe), the effect of lowering $\left[\mathrm{CO}_{2}\right]$ is to strengthen the expression of warmer and/or wetter climates. The strength and nature of the response to lowering $\left[\mathrm{CO}_{2}\right]$ is also clearly affected by the nature of the vegetation transitions involved: the impact of lowering $\left[\mathrm{CO}_{2}\right]$ is most clearly expressed where there are transitions between forest and non-forest xerophytic vegetation (e.g. the continental interior).

\section{Discussion}

Analyses of a suite of OAGCM simulations of 6 ka show that there are a number of robust changes in regional 
climate and vegetation in response to orbital forcing. These robust features include (a) the reduction of tundra in high northern latitudes, (b) the northward expansion of temperate forests in eastern North America, and (c) the expansion of xerophytic vegetation in mid-continental Eurasia.

\subsection{Reduction of tundra in high northern latitudes}

All of the models produce a northward shift in the boundary between boreal forest and tundra. This shift is markedly asymmetric, with largest changes occurring in northern Eurasia and relatively small changes occurring over North America. The changes in tundra area are caused by warmer conditions during the growing season, partly driven by orbitally forced changes in summer temperature and partly driven by warming in autumn because of ocean feedback (see Wohlfahrt et al. 2004). The marked asymmetry in the changes in the tundra-taiga boundary is not a feature of most atmosphere-only simulations (see e.g. TEMPO 1996). This suggests that changes in the Arctic Ocean play an important role in producing this asymmetry, a conclusion consistent with studies of the role of changes in sea ice on high-latitude climates (Vavrus and Harrison 2003). The simulated changes in high-latitude vegetation are in good agreement with observations: in Eurasia, for example, all the models produce a match between observed and simulated vegetation at between 77 and $83 \%$ of the actual pollen sites and there is no systematic signal in the mismatches. Non-systematic errors probably arise through differences between the scale of registration of the models and the pollen sites rather than because the large-scale climate prediction is incorrect. The coarse spatial scale of the climate models means that they cannot be expected to capture the precise location of vegetation boundaries. It is also possible that, despite screening of the original pollen records, some of these sites might reflect the influence of local factors such as soil type, slope or aspect on the vegetation rather than regional climate.

\subsection{Northward expansion of temperate forests in eastern North America}

All of the models produce a northward expansion of temperate forests at the expense of boreal forest in eastern North America, in response to winter warming. Comparison with observations shows that the northward expansion of temperate forests is realistic, but too large. We have hypothesised that this overestimate of the magnitude of vegetation changes is a result of the unrealistic prescription of ice cover in the simulations, and specifically the omission of the small remnant of the Laurentide ice sheet that persisted in Quebec until well after $6 \mathrm{ka}$. Although there have been no simulations of the $6 \mathrm{ka}$ climate which incorporate this ice sheet, simulations of the early Holocene (ca. $9 \mathrm{ka}$ ) climate made with and without the presence of ice in eastern Canada show that this ice mass has a nonnegligible effect on regional temperatures (Mitchell et al. 1988). There are no plans to incorporate the relict Laurentide ice sheet in the $6 \mathrm{ka}$ simulations planned within the next round of PMIP (http://www-lsce.cea.fr/pmip/), although this ice sheet will be included in planned early Holocene (11 ka) simulations. Our analyses suggest that this will limit the usefulness of comparisons with pollenbased vegetation reconstructions from eastern North America (e.g. Williams et al. 2000) and suggest that there is a need to run both mid-Holocene and early-Holocene experiments incorporating changes in ice cover in order to fully understand the evolution of North American climates during the Holocene.

\subsection{Expansion of xerophytic vegetation in Eurasia}

All of the OAGCM simulations produce a significant expansion of xerophytic vegetation in the mid-continent of Eurasia. The robustness of this signal across the suite of simulations is a matter of concern because the simulated expansion is not consistent with observations. In a diagnosis of the IPSL-CMI simulation, Wohlfahrt et al. (2004) have shown that the expansion of xerophytic vegetation in mid-continental Eurasia is already present in atmosphereonly simulations, and is amplified by ocean feedback. When these simulated changes in vegetation are used to prescribe land-surface conditions in a second OAGCM simulation, they produce a further increase in aridity resulting in a considerable expansion of xerophytic vegetation and a further degradation of the match between simulated and observed vegetation patterns (Fig. 13). A similar result would be produced if simulated vegetation patterns from any of the OAGCM simulations analysed here were used to prescribe vegetation changes in $6 \mathrm{ka}$ experiments. Previous analyses of coupled OAGCM simulations have emphasised the role of ocean feedback in improving simulated regional climates (e.g. Kutzbach et al. 2001). However, as our analyses show, the incorporation of both ocean- and land-surface feedbacks has the potential to produce less realistic simulations of the climate. The tendency for models to produce more arid conditions in central Eurasia than shown by palaeoenvironmental data was already apparent in analyses of earlier AGCM simulations (see e.g. Yu and Harrison 1996; Qin et al. 1998; Tarasov et al. 1998). However, the cause of this mismatch was unclear. Our analyses suggest that the simulated increase in aridity is primarily a function of temperaturedriven increases in evapotranspiration during the growing season. Simulated changes in precipitation are not 


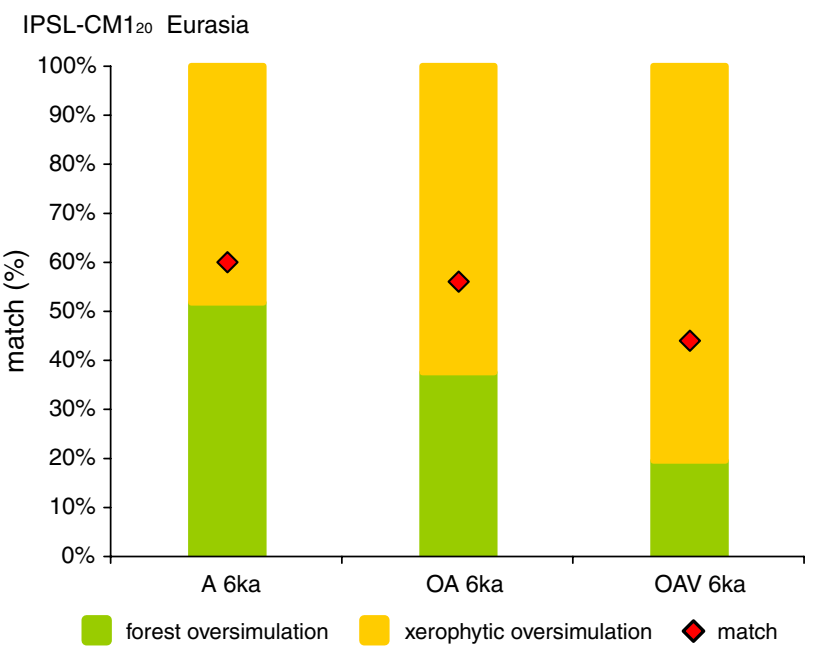

Fig. 13 Comparison of observed vegetation changes in Eurasia (70$\left.140^{\circ} \mathrm{E}, 40-60^{\circ} \mathrm{N}\right)$ and changes as simulated by the IPSL model with 20 years averages (IPSL-CM1 $1_{20}$ ) as a result of $\mathbf{a}$ the atmosphere-only response (A $6 \mathrm{ka})$, b the coupled ocean-atmosphere response (OA $6 \mathrm{ka})$, and $\mathrm{c}$ the coupled ocean-atmosphere-vegetation response (OAV $6 \mathrm{ka}$ ) to $6 \mathrm{ka}$ orbital forcing (Wohlfahrt et al. 2004). The red diamonds show the overall match $(\%)$ between observation and simulated changes for each simulation. The stacked bars show the relative proportion of the mismatches that are due to simulation of forest in areas where the observed vegetation was xerophytic (forest oversimulation) or the simulation of xerophytic in areas where the observed vegetation was forest (xerophytic oversimulation)

consistent from model to model, with some models producing decreased precipitation during summer and others producing a marked increase in precipitation.

Our analyses show that some features of the response of the coupled ocean-atmosphere system to $6 \mathrm{ka}$ orbital forcing are not robust from model to model. Specifically, the models have different responses in (a) the mid-continent of North America and (b) over Europe. It is possible that these inter-model differences in response reflect differences between the control simulations. Analyses of the response of the northern African monsoon to $6 \mathrm{ka}$ orbital forcing (Joussaume et al. 1999; Braconnot et al. 2002), for example, show that inter-model differences in the location of the simulated monsoon front in the control partly determine the magnitude of the response to changes in orbital forcing.

\subsection{Mid-continental North America}

The models differ in the degree to which they produce an increase in xerophytic vegetation in mid-continental North America, although only the CSM1.2 $\Delta$ simulation fails to produce an increase. Harrison et al. (2003) have shown that mid-continental aridity is dynamically linked to the simulation of an enhanced monsoon in western North America: precipitation is suppressed in the regions characterised by subsidence around the monsoon core. This suggests that the differences in magnitude of the expansion of xerophytic vegetation is likely to be correlated with differences in the strength of the simulated monsoon expansion in North America (not examined here) and could help to explain the correlation between changes in the area of xerophytic vegetation and summer temperature.

\subsection{Europe}

The simulated changes in vegetation patterns over Europe differ from model to model: most of the models produce an increase in the extent of temperate forests but the IPSLCMI and CSM models produce a decrease. In our previous analyses of the IPSL model, we showed that ocean feedback enhanced the orbitally induced winter cooling over Europe shown in atmosphere-only simulations and that vegetation feedback was necessary to produce a quasirealistic northward expansion of temperate forests in this region. Our current comparisons show that this conclusion needs to be revisited. In the absence of atmosphere-only simulations associated with the current OAGCM runs, we are unable to say whether the differences between the models are already apparent in the atmospheric response to orbital forcing or are a consequence of differences in ocean feedbacks. However, even those models which show winter warming over Europe fail to produce a large enough warming to reproduce the northward expansion of temperate forests show by the observations. Thus, the conclusion that vegetation feedback is necessary to simulate mid-Holocene climate changes over Europe correctly is still likely to be true.

\section{Conclusion}

In these analyses, we have developed a number of diagnostics based on comparison of simulated regional vegetation changes and reconstructions of northern hemisphere extratropical vegetation patterns from pollen and plant macrofossil data. These diagnostics provide both a quantitative assessment of the match between the simulations and observations, and a way of identifying the climatic implications of the mismatches. The vegetation data set that we have assembled from existing syntheses (Prentice et al. 2000; Bigelow et al. 2003) represents the most comprehensive data set for 6 ka currently available. Nevertheless, there are some regions where the data are sparse (e.g. central and north Eurasia) and other regions where the sites are not very well dated (e.g. in central Canada or eastern Europe). Both of these issues could place limits on our ability to diagnose differences between climate simulations. Thus, it is important that the work of the 
BIOME 6000 project is continued and the existing data sets are expanded and improved. Nevertheless, we have shown that these diagnostics can discriminate between correct (e.g. the simulation of changes in the tundra-taiga boundary) and broadly incorrect (e.g. the simulation of increased aridity in central Eurasia) model responses. We have also shown that these diagnostics can discriminate between models, for example in showing that the CSM1.2A simulation produces a different response in western North America to the other models. Thus, we anticipate that these diagnostics will provide a useful tool for the evaluation of coupled model simulations in the current phase of the PMIP project (Harrison et al. 2002; http://www-lsce.cea. fr/pmip2/).

Acknowledgments This paper is a contribution to the EU-funded MOTIF project, to its international counterpart PMIP II, and to the DEKLIM project "Past climate sensitivity and variability" funded by BMBF. We thank Kerstin Sickel for her help in running the BIOME4 simulations, Patrick Bartlein for his comments on an earlier presentation of these results, Céline Bonfils for a helpful review of the original manuscript, and an anonymous reviewer for comments on the final version of the manuscript.

Open Access This article is distributed under the terms of the Creative Commons Attribution Noncommercial License which permits any noncommercial use, distribution, and reproduction in any medium, provided the original author(s) and source are credited.

\section{References}

Berger A (1978) Long-term variations of daily insolation and Quaternary climatic changes. J Atmos Sci 35:2362-2367

Bigelow NH, Brubaker LB, Edwards ME, Harrison SP, Prentice IC, Anderson PM, Andreev AA, Bartlein PJ, Christensen TR, Cramer W, Kaplan JO, Lozhkin AV, Matveyeva NV, Murray DF, McGuire AD, Razzhivin AY, Ritchie JC, Smith B, Walker DA, Galjewski K, Wolf V, Holmquist B, Igarashi Y, Kremenetskii K, Paus A, Pisaric MFJ, Volkova VS (2003) Climate change and Arctic ecosystems-I. Vegetation changes north of $50^{\circ} \mathrm{N}$ between the last glacial maximum, mid-Holocene and present. J Geophys Res, vol 108. doi:10.1029/2002JD002558

Bonan GB (1998) The land surface climatology of the NCAR Land Surface Model coupled to the NCAR Community Climate Model. J Clim 11:1307-1326

Bonan GB, Pollard D, Thompson SL (1992) Effects of boreal forest vegetation on global climate. Nature 359:716-718

Braconnot P, Joussaume S, de Noblet N, Ramstein G (2000a) MidHolocene and Last Glacial Maximum African monsoon changes as simulated within the Paleoclimate Modelling Intercomparison Project. Glob Planet Change 26:51-66

Braconnot P, Joussaume S, Marti O, de Noblet N (1999) Synergistic feedbacks from ocean and vegetation on the African monsoon response to mid-Holocene insolation. Geophys Res Lett 26:2481-2484

Braconnot P, Loutre MF, Dong B, Joussaume S, Valdes P (2002) How the simulated change in monsoon at $6 \mathrm{ka} \mathrm{BP}$ is related to the simulation of the modern climate: results from the Paleoclimate Modeling Intercomparison Project. Clim Dyn 19:107-121
Braconnot P, Marti O, Joussaume S, Leclainche Y (2000b) Ocean feedback in response to $6 \mathrm{kyr}$ BP insolation. J Clim 13:15371553

Brovkin V, Levis S, Loutre MF, Crucifix M, Claussen M, Ganopolski A, Kubatzki C, Petoukhov V (2003) Stability analysis of the climate-vegetation system in the northern high latitudes. Clim Change 57(1):119-138

CAPE Project Members (2001) Holocene paleoclimate data from the Arctic: testing models of global climate change. Quat Sci Rev 20:1275-1287

Clark CD, Knight JK, Gray JT (2000) Geomorphological reconstruction of the Labrador Sector of the Laurentide Ice Sheet. Quat Sci Rev 19:1343-1366

COHMAP Members (1988) Climatic change of the last 18,000 years: observations and model simulations. Science 241:1043-1052

Douville H, Royer JF (1996) Sensitivity of the Asian summer monsoon to an anomalous Eurasian snow cover within the Meteo-France GCM. Clim Dyn 12:449-466

Ducoudré NI, Laval K, Perrier A (1993) SECHIBA, a new set of parameterizations of the hydrologic exchanges at the land atmosphere interface within the LMD atmospheric general circulation model. J Clim 6:248-273

Edwards ME, Anderson PM, Brubaker LB, Ager TA, Andreev AA, Bigelow NH, Cwynar LC, Eisner WR, Harrison SP, Hu F-S, Jolly D, Lozhkin AV, MacDonald GM, Mock CJ, Ritchie JC, Sher AV, Spear RW, Williams JW, Yu G (2000) Pollen-based biomes for Beringia 18,000, 6000 and 0 14C yr BP. J Biogeogr 27:521-554

FAO (1995) Digital soil map of the world and derived soil properties. Food and Agriculture Organization, Rome

Guiot J, Boreux JJ, Braconnot P, Torre F, Participants P (1999) Datamodel comparison using fuzzy logic in paleoclimatology. Clim Dyn 15:569-581

Harrison SP, Braconnot P, Joussaume S, Hewitt C, Stouffer RJ (2002) Comparison of palaeoclimate simulations enhances confidence in models. Eos, Transactions, American Geophysical Union 83:447-447

Harrison SP, Jolly D, Laarif F, Abe-Ouchi A, Dong B, Herterich K, Hewitt C, Joussaume S, Kutzbach JE, Mitchell J, De Noblet N, Valdes $\mathrm{P}$ (1998) Intercomparison of simulated global vegetation distributions in response to $6 \mathrm{kyr} \mathrm{BP}$ orbital forcing. J Clim 11:2721-2742

Harrison SP, Kutzbach JE, Liu Z, Bartlein PJ, Otto-Bliesner BL, Muhs D, Prentice IC, Thompson RS (2003) Mid-Holocene climates of the Americas: a dynamical response to changed seasonality. Clim Dyn 20:663-688. doi:10.1007/s0038200002-00300-00386

Harrison SP, Prentice IC (2003) Climate and $\mathrm{CO}_{2}$ controls on global vegetation distribution at the last glacial maximum: analysis based on palaeovegetation data, biome modelling and palaeoclimate simulations. Glob Change Biol 9:983-1004

Hewitt CD, Broccoli AJ, Mitchell JFB, Stouffer RJ (2001) A coupled model study of the last glacial maximum: Was part of the North Atlantic relatively warm? Geophys Res Lett 28:1571-1574

Hewitt CD, Mitchell JFB (1998) A fully coupled GCM simulation of the climate of the mid- Holocene. Geophys Res Lett 25:361-364

Johns TC, Carnell RE, Crossley JF, Gregory JM, Mitchell JFB, Senior CA, Tett SFB, Wood RA (1997) The second Hadley Centre coupled ocean-atmosphere GCM: model description, spinup and validation. Clim Dyn 13:103-134

Jolly D, Prentice IC, Bonnefille R, Ballouche A, Bengo M, Brenac P, Buchet G, Burney D, Cazet JP, Cheddadi R, Edorh T, Elenga H, Elmoutaki S, Guiot J, Laarif F, Lamb H, Lezine AM, Maley J, Mbenza M, Peyron O, Reille M, Reynaud-Farrera I, Riollet G, Ritchie JC, Roche E, Scott L, Ssemmanda I, Straka H, Umer M, Van Campo E, Vilimumbalo S, Vincens A, Waller M (1998) 
Biome reconstruction from pollen and plant macrofossil data for Africa and the Arabian peninsula at 0 and 6000 years. J Biogeogr 25:1007-1027

Joussaume S, Taylor KE (2000) The Paleoclimate Modeling Intercomparison Project. In: Braconnot P (ed) Proceedings of the third PMIP workshop. WCRP, La Huardière, Canada, 4-8 October 1999, pp 9-25

Joussaume S, Taylor KE, Braconnot P, Mitchell JFB, Kutzbach JE, Harrison SP, Prentice IC, Broccoli AJ, Abe-Ouchi A, Bartlein PJ, Bonfils C, Dong B, Guiot J, Herterich K, Hewitt CD, Jolly D, Kim JW, Kislov A, Kitoh A, Loutre MF, Masson V, McAvaney B, McFarlane N, de Noblet N, Peltier WR, Peterschmitt JY, Pollard D, Rind D, Royer JF, Schlesinger ME, Syktus J, Thompson S, Valdes P, Vettoretti G, Webb RS, Wyputta U (1999) Monsoon changes for 6000 years ago: results of 18 simulations from the Paleoclimate Modeling Intercomparison Project (PMIP). Geophys Res Lett 26:859862

Kageyama M, Valdes PJ, Ramstein G, Hewitt C, Wyputta U (1999) Northern hemisphere storm tracks in present day and Last Glacial Maximum climate simulations: a comparison of the European PMIP models. J Clim 12:742-760

Kaplan JO, Bigelow NH, Prentice IC, Harrison SP, Bartlein PJ, Christensen TR, Cramer W, Matveyeva NV, McGuire AD, Murray DF, Razzhivin VY, Smith B, Walker DA, Anderson PM, Andreev AA, Brubaker LB, Edwards ME, Lozhkin AV (2003) Climate change and arctic ecosystems II. Modeling, paleodatamodel comparisons, and future projections. J Geophys Res, vol 108. doi: $10.1029 / 2002$ JD002559

Kitoh A, Murakami S (2002) Tropical Pacific climate at the midHolocene and the Last Glacial Maximum simulated by a coupled ocean-atmosphere general circulation model. Paleoceanography, vol 17. doi:10.1029/2001PA000724

Kohfeld KE, Harrison SP (2000) How well can we simulate past climates? Evaluating the models using global palaeoenvironmental datasets. Quat Sci Rev 19:321-346

Kutzbach JE (1981) Monsoon climate of the early Holocene: climate experiment with the earth's orbital parameters for 9000 years ago. Science 214:59-61

Kutzbach JE, Guetter PJ (1986) The influence of changing orbital parameters and surface boundary conditions on climate simulations for the past 18000 years. J Atmos Sci 43:1726-1759

Kutzbach JE, Guetter PJ, Behling PJ, Selin R (1993) Simulated climatic changes: results of the COHMAP climate-model experiments. In: Wright HE Jr, Kutzbach JE, Webb T III, Ruddiman WF, Street-Perrott FA, Bartlein PJ (eds) Global Climates since the Last Glacial Maximum. University of Minnesota Press, Minneapolis, pp 24-93

Kutzbach JE, Harrison SP, Coe MT (2001) Land-ocean-atmosphere interactions and monsoon climate change: a palaeo-perspective. In: Schulze E-D, Heimann M, Harrison SP, Holland E, Lloyd J, Prentice IC, Schimel DS (Max-Planck-Institute for Biogeochemistry J, Germany) (eds) Global biogeochemical cycles in the climate system. Academic Press, San Diego, pp 73-83

Kutzbach JE, Liu Z (1997) Response of the African monsoon to orbital forcing and ocean feedbacks in the middle Holocene. Science 278:440-443

Kutzbach JE, Otto-Bliesner BL (1982) The sensitivity of the AfricanAsian monsoonal climate to orbital parameter changes for 9000 years B.P. in a low-resolution general circulation model. J Atmos Sci 39:1177-1188

Kutzbach JE, Street-Perrott FA (1985) Milankovitch forcing of fluctuations in the level of tropical lakes from 18 to $0 \mathrm{kyr}$ BP. Nature 317:130-134

Levis S, Foley JA, Pollard D (2000) Large-scale vegetation feedbacks on a doubled $\mathrm{CO}_{2}$ climate. J Clim 13:1313-1325
Levitus S (1982) Climatological atlas of the world's oceans, vol 13, NOAA/ERL GFDL Professional paper 13, Princeton, NJ, $173 \mathrm{pp}$

Liu Z, Harrison SP, Kutzbach JE, Otto-Bliesner B (2004) Global monsoons in the mid-Holocene and oceanic feedback. Clim Dyn 22:157-182. doi:110.1007/s00382-00003-00372-y

MacDonald GM, Felzer B, Finney BP, Forman ST (2000) Holocene lake sediment records of Arctic hydrology. J Paleolimnol 24:1-14

Marshall SJ, Tarasov L, Clarke GKC, Peltier WR (2000) Glaciological reconstruction of the Laurentide Ice Sheet: physical processes and modelling challenges. Canad J Earth Sci 37:769-793

Masson V, Cheddadi R, Braconnot P, Joussaume S, Texier D (1999) Mid-Holocene climate in Europe: What can we infer from PMIP model data comparisons? Clim Dyn 15:163-182

Masson V, Joussaume S (1997) Energetics of the 6000-yr BP atmospheric circulation in boreal summer, from large-scale to monsoon areas: a study with two versions of the LMD AGCM. J Clim 10:2888-2903

Mikolajewicz U, Scholze M, Voss R (2003) Simulating nearequilibrium climate and vegetation for $6000 \mathrm{cal}$. years BP. Holocene 13:319-326

Mitchell JFB, Grahame NS, Needham KJ (1988) Climate simulations for 9000 years before present: seasonal variations and effect of the Laurentide ice sheet. J Geophys Res-Atmos 93:8283-8303

Otto-Bliesner BL (1999) El Niño/La Niña and Sahel precipitation during the middle Holocene. Geophys Res Lett 26:87-90

Prentice IC, Guiot J, Huntley B, Jolly D, Cheddadi R (1996) Reconstructing biomes from palaeoecological data: a general method and its application to European pollen data at 0 and $6 \mathrm{ka}$. Clim Dyn 12:185-194

Prentice IC, Jolly D, BIOME 6000 Participants (2000) Mid-Holocene and glacial-maximum vegetation geography of the northern continents and Africa. J Biogeogr 27:507-519

Prentice IC, Webb T (1998) BIOME 6000: reconstructing global midHolocene vegetation patterns from palaeoecological records. J Biogeogr 25:997-1005

Qin BQ, Harrison SP, Kutzbach JE (1998) Evaluation of modelled regional water balance using lake status data: a comparison of 6 ka simulations with the NCAR CCM. Quat Sci Rev 17:535548

Raynaud D, Jouzel J, Barnola JM, Chappellaz J, Delmas RJ, Lorius C (1993) The ice record of greenhouse gases. Science 259:926-934

Semtner AJ (1976) Model for thermodynamic growth of sea ice in numerical investigations of climate. J Phys Oceanogr 6:379-389

Street-Perrott FA, Perrott RA (1993) Holocene vegetation, lake levels, and climate of Africa. In: Wright HE, Kutzbach JE, Webb III T, Ruddiman WF, Street-Perrott FA, Bartlein PJ (eds) Global climates since the last glacial maximum. University of Minnesota Press, Minneapolis, pp 318-356 (569 pp)

Tarasov PE, Webb T III, Andreev AA, Afanas'eva NB, Berezina NA, Bezusko LG, Blyakharchuk TA, Bolikhovskaya NS, Cheddadi R, Chernavskaya MM, Chernova GM, Dorofeyuk NI, Dirksen VG, Elina GA, Filimonova LV, Glebov FZ, Guiot J, Gunova VS, Harrison SP, Jolly D, Khomutova VI, Kvavadze EV, Osipova IM, Panova NK, Prentice IC, Saarse L, Sevastyanov DV, Volkova VS, Zernitskaya VP (1998) Present-day and midHolocene biomes reconstructed from pollen and plant macrofossil data from the former Soviet Union and Mongolia. J Biogeogr 25:1029-1053

TEMPO (1996) Potential role of vegetation feedback in the climate sensitivity of high-latitude regions: a case study at 6000 years before present. Glob Biogeochem Cycle 10:727-736

Texier D, de Noblet N, Braconnot P (2000) Sensitivity of the African and Asian monsoons to mid-Holocene insolation and datainferred surface changes. J Clim 13:164-181 
Vavrus SJ, Harrison SP (2003) The impact of sea-ice dynamics on the Arctic climate system. Clim Dyn 20:741-757. doi: 10.1007/s00382-00003-00309-00385

Voss R, Mikolajewicz U (2001) The climate of 6000 years BP in near-equilibrium simulations with a coupled AOGCM. Geophys Res Lett 28:2213-2216

Warrilow DA, Sangster AB, Slingo A (1986) Modelling of land surface processes and their influence on European climate. Technical report DCTN 38, United Kingdom Meteorological Office, Bracknell, Berkshire RG12 2SZ, UK

Weatherley JW, Briegleb BP, Large WG, Maslanik JA (1998) Sea ice and polar climate in the NCAR Csm. J Clim 11:1472-1486

Weber SL (2001) The impact of orbital forcing on the climate of an intermediate-complexity coupled model. Glob Planet Change 30:7-12

Weber SL, Oerlemans J (2003) Holocene glacier variability: three case studies using an intermediate-complexity climate model. Holocene 13:353-363
Williams JW, Webb T III, Richard PH, Newby P (2000) Late Quaternary biomes of Canada and the eastern United States. J Biogeogr 27:585-607

Wohlfahrt J, Harrison SP, Braconnot P (2004) Synergistic feedbacks between ocean and vegetation on mid- and high-latitude climates during the mid-Holocene. Clim Dyn 22:223-238

Woodruff S, Slutz RJ, Jenne RL, Steurer P (1987) A comprehensive ocean-atmosphere data set. Bull Amer Meteor Soc 68:12391250

Yu G, Harrison SP (1995) Holocene changes in atmospheric circulation patterns as shown by lake status changes in northern Europe. Boreas 24:260-268

Yu G, Harrison SP (1996) An evaluation of the simulated water balance of Eurasia and northern Africa at 6000 y BP using lake status data. Clim Dyn 12:723-735

Yu G, Prentice IC, Harrison SP, Sun XJ (1998) Pollen-based biome reconstructions for China at 0 and 6000 years. J Biogeogr 25:1055-1069 